\title{
Is There a Glass Ceiling in Sweden?
}

\author{
James Albrecht \\ Department of Economics, Georgetown University \\ albrecht@georgetown.edu \\ Anders Björklund \\ Swedish Institute for Social Research (SOFI), Stockholm University \\ anders@sofi.su.se \\ Susan Vroman \\ Department of Economics, Georgetown University \\ vromans@georgetown.edu
}

July 2001

\begin{abstract}
:
Using data from 1998, we show that the gender log wage gap in Sweden increases throughout the wage distribution and accelerates in the upper tail of the distribution, which we interpret as a glass ceiling effect. Using earlier data, we show that the same pattern held at the beginning of the 1990's but not in the prior two decades. Further, we do not find this pattern either for the log wage gap between immigrants and nonimmigrants in the Swedish labor market or for the gender gap in the U.S. labor market. Our findings suggest that a gender-specific mechanism in the Swedish labor market hinders women from reaching the top of the wage distribution. Using quantile regressions, we examine whether this pattern can be ascribed primarily to gender differences in labor market characteristics or to gender differences in rewards to those characteristics. We estimate pooled quantile regressions with gender dummies, as well as separate quantile regressions by gender, and we carry out a decomposition analysis in the spirit of the Oaxaca-Blinder technique. Even after extensive controls for gender differences in age, education (both level and field), sector, industry, and occupation, we find that the glass ceiling effect we see in the raw data persists to a considerable extent.
\end{abstract}

JEL Classification: J16, J71

Keywords: gender gap, glass ceiling, quantile regression

* We thank seminar participants, especially at the 2000 EALE/SOLE meetings and at IFAU (Uppsala), for helpful comments, Peter Norman for a useful conversation that led to Figure 4, and Fredrik Andersson for programming advice. Finally, we thank the Swedish Council for Social Research (SFR) for financial support. 


\section{Introduction}

Is there a glass ceiling in Sweden? Using micro data from 1998, we find that the gender log wage gap (hereafter simply the "gender gap") increases throughout the wage distribution with a sharp acceleration in the upper tail of the distribution. We interpret this as strong evidence of a glass ceiling.

Previous work on the gender gap in Sweden focussed on the average log wage gap between men and women. A micro dataset containing individual wage data was first available in Sweden in 1968. At that time, the average raw wage gap between men and women was estimated to be almost 30\%. The same survey was also carried out in 1981 and 1991. By 1981, the average gender gap had declined by about ten percentage points, but this gap then remained more or less stable to 1991 and then, according to our data, increased slightly by the end of the 1990's. These developments in the average gender gap appear to have been driven by corresponding developments in the overall wage distribution (Edin and Richardsson, 2001). The importance of the overall wage distribution for the magnitude of the average gender gap is also emphasized by Blau and Kahn (1996). Their analysis suggests that, in the early 1980s, the markedly larger average gender gap in the United States compared to Sweden could be explained by higher overall U.S. wage inequality.

Several attempts have been made to estimate the extent to which the average gender gap is due to differences in human capital attributes such as schooling and work experience versus the extent to which it is due to differences between genders in wages paid for given attributes. Less than half of the gap can be explained by factors such as differences in years of schooling, experience, and tenure (Le Grand 1991, Edin and Richardsson 2001). Further, differences in working conditions do not seem to matter at all for the gender gap (Palme and Wright 1992).

All of the above-mentioned work examines only average log wage gaps. This work is interesting, but it cannot address the question of whether women encounter a glass ceiling. By a glass ceiling, we mean the phenomenon whereby women do quite well in the labor market up to a point after which there is an effective limit on their prospects. The existence of a glass ceiling would imply that women's wages fall behind men's more at the top of the wage distribution than at the middle or bottom. To investigate whether a 
glass ceiling exists obviously requires that the gender gap be examined in different parts of the distribution.

In this paper, we document the existence of a significant glass ceiling effect in Sweden in the 1990's. That is, the average gender gap in Sweden in the 1990's is mainly attributable to the gap at the top of the wage distribution. We examine other wage gaps to see whether this is a general phenomenon. We find that this effect was much less pronounced in the 1981 data and was not at all evident in the 1968 data. Thus, the glass ceiling appears to be a phenomenon of the 1990's in Sweden. We also look at the wage gap between recent immigrants and other workers in Sweden. Unlike the gender log wage gap, the immigrant log wage gap is essentially constant over the entire wage distribution. This suggests that the glass ceiling effect is purely a gender-specific phenomenon. Finally, we look at 1999 data from the United States and do not find a comparable pattern. Indeed, the gender gap at the top of the Swedish wage distribution is larger than the corresponding gap in the United States despite a much larger average gender gap in the United States.

We then turn to explanations. We examine the extent to which the pattern of gender gaps over the wage distribution can be accounted for by differences between men and women in their characteristics versus differences in the returns to those characteristics. We estimate quantile regressions at various percentiles of the wage distribution as well as separate quantile regressions by gender. Finally, we carry out a Oaxaca-Blinder type decomposition using quantile methods. This allows us to address our basic question across the wage distribution. Controlling for education (both level and field), age, immigrant status, sector and industry of employment, we find that gender differences in returns to labor market characteristics are the more important factor. When we add a detailed occupational control, differences in returns still account for most of the gender gap at the bottom of the distribution, but, at the top of the distribution, differences in returns and differences in characteristics each account for about half of the gender gap.

The remainder of the paper is organized as follows. In the next section, we describe our data sources. Our findings with respect to the observed gender gaps are presented in a series of figures in Section 3. Section 4 contains the results of our quantile regressions, 
both pooled and by gender, and our decomposition analysis. The last section contains concluding remarks.

\section{Data}

We use several Swedish datasets. Our primary dataset is the so-called LINDA data. This is a special dataset created by Statistics Sweden (SSW) for research purposes (see Edin and Fredriksson, 2000). LINDA is based on a random sample in 1994 of approximately 300,000 people of all ages. ${ }^{1}$ The sample is followed over time as a panel and is complemented each year with new immigrants and newly born individuals to make it a nationally representative dataset in each year. The variables in LINDA are primarily taken from SSW's registers. For the 1998 data, SSW ensured that the employers of the complete LINDA sample reported monthly earnings information. We thus have monthly earnings information for all employed persons, except the self-employed. The monthly earnings figures are expressed in full-time equivalents, that is, they give the amount the individual would have earned had he or she worked full time.

The major advantages of this data source are the earnings data and the large sample size. The drawback is that only a few explanatory variables are available; most notably, actual work experience is missing. On the other hand, there is good information about educational attainment in these data. Specifically, information on educational level and field is taken from SSW's education register of the population.

We also use data from SSW for 1992. These 1992 data were collected from employers in the same manner as the LINDA data. Employers reported monthly earnings, working hours, occupation and some additional information for their employees. These

\footnotetext{
${ }^{1}$ LINDA also contains information about the household members of the sampled persons, as well as a special sample of immigrants to Sweden. However, we only use the random sample of the Swedish population, which of course also contains immigrants.

${ }^{2}$ We use seven education levels. Ed1: less than nine years of education (folkskola and incomplete comprehensive school, grundskola). Ed2: nine or ten years of basic education, i.e. comprehensive school (grundskola) or junior secondary school (realskola). Ed3: upper secondary school for up to two years (kortare gymnasium). Ed4: upper secondary school (high school) for three years (längre gymnasium). Ed5: post secondary schooling for less than three years (kortare universitetsutbildning). Ed6: at least three years of post secondary education (längre universitetsutbildning). Ed7: completed doctoral degree (forskarutbildning). In some estimations, we also use field of education, namely: 1. General education, 2. Arts, Humanities, and Religion, 3. Teacher Training, 4. Administration, Economics, Social Science, and Law, 5. Industry and Technology, 6. Transport and Communication, 7. Health, 8. Agriculture, Forestry, and Fishing, 9. Service and Defense, and 10. unspecified.
} 
data cover all employed persons in the public sector and parts of the private sector. ${ }^{\text {G }}$ For the part of the private sector that is not completely covered, SSW took a random sample of firms. We took a subsample of the data by applying a subsample weight equal to 0.01 times SSW's sample weight. This generated a simple random sample of around 29,000 workers.

Finally, we also use data from the 1968, 1981 and 1991 waves of the Swedish Level of Living Surveys (SLLS). 4 In contrast to the SSW data, the SLLS data are based on interviews with individuals. This data source is the one most commonly used in previous research. It contains information about many determinants of individuals' wages. In

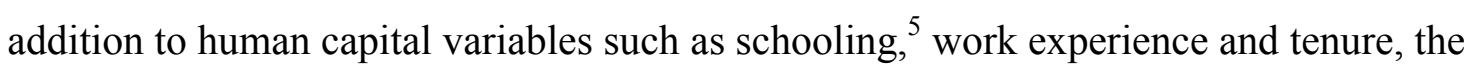
dataset provides information about self-reported working conditions as well as several demographic characteristics. In these data, the hourly wage is measured using information from a sequence of questions. A question is first asked about the mode of pay, whether it is by hour, by week, by month, by piece rate, etc. Conditional on the answer to this question, the next question is about the pay per hour, per week etc. Finally, information about normal working hours is used to compute hourly wages for those who are not paid by the hour. The drawback of the SLLS is its small sample size. The survey is basically a representative sample of one per thousand of the population aged 15-75 years (18-75 in 1991) in each year. This yields roughly 3,000 observations of employed male and female workers in each year.

Table 1 summarizes the five different samples that we use. The data from the three waves of the SLLS show that the average gender gap declined from 33\% in 1968 to $18 \%$ in 1981 and then rose somewhat to $20 \%$ in $1991 .^{6}$ All wages are in nominal terms. Note also that the SLLS and SSW wage data are expressed in different units, namely hourly and monthly, respectively. The well-known overall wage compression that took place during the 1970's is demonstrated by the fact that both the standard deviation of the log wage and the 90/10 percentile ratio fell sharply from 1968 to 1981 for both men and women. That the $90 / 50$ and 50/10 percentile ratios declined as well shows that the

\footnotetext{
${ }^{3}$ For more information, see Statistics Sweden (1992).

${ }_{5}^{4}$ For more information, see Erikson and Åberg (1987).

5 The 1991 SLLS data also contain information on education from Statistics Sweden's education register.
} 
compression took place in both parts of the wage distribution. In terms of explanatory variables in the SLLS data, there are almost no gender differences in years of schooling but, as expected, men have more work experience than women, even though the differential is falling over time. Further, men more often work in the private sector.

The data from Statistics Sweden show a smaller average gender gap in the early 1990 's - 15\% in 1992 compared to $20 \%$ in the 1991 wave of the SLLS. Further, both the standard deviation of the log wage and the percentile ratios reveal less wage inequality in the SSW data. Even though there is a year and a half between the data collection points the SLLS data were collected in the spring of 1991 and the SSW wages refer to the fall of 1992 - the differences are more likely due to differences in measurement than to changes in the real wage structure. It is not clear which wage data are more reliable. ${ }^{\text {Both }}$ data sources probably suffer from measurement error. We estimate wage equations with identical regressors, and find that the explanatory power is somewhat higher in the SSW data (see Table A1). This finding, together with the lower wage inequality in the SSW data, is consistent with less classical measurement error in these data.

From 1992 to 1998, earnings inequality increased in all the dimensions reported in Table 1. The standard deviation of $\log$ wages as well as the P90/P50 and P50/P10 ratios rose for both men and women. The average gender gap rose slightly from $15 \%$ to $16 \%$. Further, educational attainment rose over the 1990s, so that a larger fraction of women than of men had long university training (level 6) in 1998.

\section{Basic Log Wage Gaps -- Figures}

In this section, we present some of our basic findings using a series of figures. Our main finding is that the gender gap in Sweden is much larger at the top of the distribution than at the bottom. This pattern is characteristic of the 1990's. A similar pattern, although not as pronounced, is present in 1981, but data from 1968 do not show this pattern. We also examine the immigrant-nonimmigrant wage gap in Sweden in 1998, but find that the gap is essentially constant throughout the distribution. We take this as evidence that a gap that increases as one moves up the wage distribution is a gender-specific phenomenon.

\footnotetext{
${ }^{6}$ These gender gaps are, in fact, log wage differences. We refer to them as percents and will continue to do so through the rest of the paper, even though a log difference of 0.33 corresponds to a $39.1 \%$ gap.

${ }^{7}$ Note that both the SSW and the SLLS data exclude the self-employed.
} 
Finally, this phenomenon seems to be much more important in Sweden than it is in the U.S.

Figure 1, which is based on the 1998 data, shows the observed gender gap at each percentile in the wage distribution. Thus, for example, at the $75^{\text {th }}$ percentile, we see a gender gap of slightly less than $20 \%$. That is, the log wage of the man at the $75^{\text {th }}$ percentile of the male wage distribution is a bit less than 20 points above the log wage of the female at the $75^{\text {th }}$ percentile of the female wage distribution.

The important features of this figure are (i) male and female wages are close to equal at the bottom of the wage distribution, (ii) male and female wages are extremely unequal (up to a maximum log wage difference of about 0.4 ) at the top of the distribution, ${ }_{\text {(iii) }}$ there is a steady increase in the gender gap as we move up in the wage distribution, and (iv) there is a sharp acceleration in the increase in the gender gap starting at about the $75^{\text {th }}$ or $80^{\text {th }}$ percentile in the wage distribution. It is this final aspect of the gender gap by percentile that we interpret as a glass ceiling.

The same basic patterns can be seen in the figure based on the $1992 \mathrm{SSW}$ data (Figure 2). Relative to 1998, the 1992 data show a bit less overall inequality but a slightly stronger glass ceiling effect. Figure 3 shows the gender gap by percentile using the 1968, 1981, and 1991 SLLS datasets. The same basic patterns can also be seen in the 1991 SLLS dataset, although there are a few notable differences; namely, there is a bit more inequality between men and women at the bottom of the distribution, a bit less inequality at the top of the distribution, and a later (around the $87^{\text {th }}$ percentile) breakpoint for the strong acceleration in male/female wage inequality. The pattern observed for the 1981 wage distribution is different. The log wage gap increases as we move up the distribution, but the sharp acceleration in the gap that we interpret as a glass ceiling effect is not present. There is also greater wage inequality at the bottom of the distribution. Finally, in 1968 , the nature of the gender gap is strikingly different. In that year, the most important gap between men and women is at the bottom of their respective distributions. It should be noted that the gender gaps shown in Figure 3 are based on many fewer observations than are the corresponding gaps in Figures 1 and 2.

\footnotetext{
${ }^{8}$ Note that a log wage gap of .4 is equivalent to a raw wage gap of about $50 \%$.
} 
The patterns we see in Figures 1-3 are consistent with the history of wage equalization efforts by Swedish unions. Centrally determined wage agreements contained clauses giving extra wage increases to members with low wages (Hibbs and Locking, 1996). These efforts were particularly strong during the 1970's and continued into the mid-1980's, and the decrease in the gender gap in the bottom of the distribution from 1968 through the early 1990's is consistent with a general attempt at wage compression. To understand the spreading in the gender gap at the top of the distribution, one might also look for a general cause. One such cause might be that the Swedish labor market is discriminatory at the top in general, but, as Figure 4 shows, the immigrant log wage gap does not expand at the top of the distribution. ${ }^{2}$ Instead this gap is essentially constant across all percentiles. Thus, it appears that the glass ceiling effect is a gender effect.

To put the 1990's patterns in the Swedish gender gap in perspective, it is useful to compare them with the corresponding U.S. patterns. Figure 5 gives the U.S. gender gap by percentile as observed in the March 1999 Current Population Survey. $\frac{10}{\text { For most }}$ percentiles, the gender gap is larger in the U.S. than in Sweden (as one would expect, since the percentage difference between average male and female wages is larger in the U.S. than in Sweden), but the gender gap is very much larger in Sweden than in the U.S. at the top of the wage distribution. The strong dip in the gender gap at the bottom of the distribution is likely attributable to the minimum wage; the dip at the very top of the distribution is probably caused by top-coding. 11 Top-coding appears to affect less than $1 \%$ of the individuals in the CPS, but this $1 \%$ figure will understate the problem if most of the top-coding applies to wages paid to males, as one would expect. However, if we look at the $75^{\text {th }}$ through the $90^{\text {th }}$ percentile, the figure differs greatly from the Swedish pattern. 12

Our Figure 5 is comparable to Figure 2a in Fortin and Lemieux (1998). They used data from the outgoing rotation groups in the 1991 Current Population Surveys on individuals' usual weekly or hourly earnings from their main jobs for their analysis. Note

\footnotetext{
${ }^{9}$ We define an immigrant to be someone not born in Sweden and who came to Sweden in 1987 or later. The result shown in Figure 4 does not appear to be sensitive to changes in the definition of immigrant.

${ }^{10}$ Wages are computed as usual weekly earnings divided by usual weekly hours.

${ }^{11}$ There is no top-coding in the Swedish data.

12 A similar analysis performed by Bonjour and Gerfin (2001) for the Swiss economy finds a smaller gender gap at the top of the distribution than at the bottom.
} 
that Fortin and Lemieux used hours-weighted wages, whereas our wages are unweighted. Nonetheless, the pattern shown in their paper is essentially the same as that shown in Figure 5. We interpret these graphs as indicating that the glass ceiling effect is stronger in Sweden than in the U.S.

A potential explanation for the patterns observed in Figures 1-3 is a compositional one. During the 1970's and early 1980's, average labor market prospects improved for women relative to men. This implies that the average log wage gap between older men and older women in the 1990's is larger than the corresponding gap for younger men and younger women. Since wages increase with experience, older workers will tend on average to have higher wages than younger workers. The combination of these two factors could generate an upward-sloping gender gap.

The gender gaps for three cohorts are shown in Figure 6. The lowest profile is for the youngest cohort of workers in the 1998 data, namely, those between the ages of 18 and 33. The other two profiles, those for workers aged 34-49 and 50-65, are very similar to each other and very different from the profile for the youngest workers in the upper tail of the distribution. Since the older workers are, on average, more highly paid than their younger counterparts, the fact that the latter two profiles lie above the one for the youngest cohort accounts for an increasing gender gap. This effect, while potentially important, does not explain the sharp acceleration in the gender gap that we see at the top of the 1990's distributions. Rather, this acceleration simply reflects the gender log wage

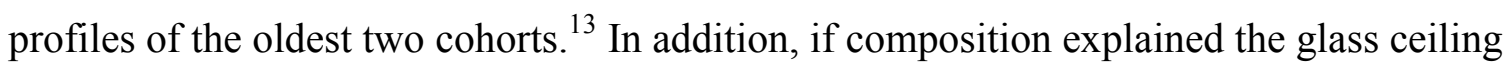
effect in Sweden, then one would expect it to also produce a glass ceiling effect in the U.S. data, where average wages for women relative to those for men have also increased over time. Since the U.S. pattern is so different from the Swedish pattern, the compositional argument does not seem compelling. Accordingly, we now investigate the traditional explanations for the gender gap, namely, that men and women differ in terms of their labor market characteristics and/or the rewards to these characteristics.

\footnotetext{
${ }^{13}$ The fact that the gender gap does not accelerate in the upper tail of the distribution for the youngest cohort might be taken as evidence that these workers do not face a glass ceiling, but, of course, one must take into account that younger workers are in the early part of their careers before age-earnings profiles typically fan out.
} 


\section{Quantile Regression Results}

In this section, we first present a series of quantile regressions to investigate the extent to which the gender gap at various percentiles can be explained by individual differences in labor market characteristics. In doing this, we impose the restriction that men and women are paid the same rewards for their labor characteristics. We next estimate separate quantile regressions for men and for women to examine the extent to which the returns to the various labor market characteristics at various percentiles differ by gender. Finally, we carry out a decomposition analysis to identify the extent to which the gender gap at various percentiles can be explained by differences between the genders in characteristics versus differences in labor-market rewards to those characteristics.

Quantile regression is a technique for estimating the $\theta^{\text {th }}$ quantile of a random variable y (log wage in our application) conditional on covariates. The quantile regression model (see, e.g., Koenker and Bassett 1978 or Buchinsky 1998) assumes that the conditional quantile of $y, q_{\theta}$, is linear in $x$; that is, $q_{\theta}=x \beta(\theta)$. The coefficient vector $\beta(\theta)$ is estimated as the solution to

$$
\min _{\beta(\theta)}\left\{\sum_{i: y_{i} \geq x_{i} \beta(\theta)} \theta\left|y_{i}-x_{i} \beta(\theta)\right|+\sum_{i: y_{i}<x_{i} \beta(\theta)}(1-\theta)\left|y_{i}-x_{i} \beta(\theta)\right|\right\} .
$$

The advantage of quantile regression over, say, ordinary least squares is that it allows one to estimate the marginal effect of a covariate on log wage at various points in the distribution, that is, not just at the mean. Thus, for example, quantile regression allows us to estimate the effect of gender, age, education, etc. on log wage at the bottom of the log wage distribution (e.g., at the $10^{\text {th }}$ percentile), at the median, and at the top of the distribution (e.g., at the $90^{\text {th }}$ percentile). In log wage quantile regressions, the coefficient estimates, $b(\theta)$, are interpreted as the estimated returns to individual characteristics at the $\theta^{\text {th }}$ quantile of the log wage distribution.

\section{A. Pooled Quantile Regressions with Gender Dummies}

We begin by investigating the extent to which the difference between the male and female log wage distributions can be attributed to differences in the characteristics that men and women bring to the labor market. Table 1 suggests three differences that are worth investigating. First, men typically have more years of work experience than women 
do, e.g., an average of 20.1 years of work experience for men versus 16.8 years for women in the 1991 SLLS data. Unfortunately, we lack a direct measure of experience in the SSW data. Second, although male and female educational attainments are essentially the same in terms of years of schooling, there are some potentially important differences in the types of education completed by men and women. For example, men are much more likely than women are to have completed a doctoral degree. We also have detailed data in 1998 on field of education that we can examine to see whether differences in education field account for some of the gender gap. Third, men are much more likely than women are to work in the private sector. In the 1998 data, $72.0 \%$ of the men versus $39.3 \%$ of the women work in the private sector. In addition to sector, we have detailed information in the 1998 data on industry of employment and occupation.

To examine the effects of differences in characteristics on the gender gap at different points in the distribution, we carry out a series of quantile regressions on the pooled 1998 dataset, that is, the combined male and female datasets. These pooled quantile regressions impose the restriction that the returns to included labor market characteristics are the same for the two genders. The estimated gender dummy coefficients in these regressions thus indicate the extent to which the gender gap remains unexplained at the various quantiles when we control for individual differences in various combinations of characteristics.

Table 2 presents the estimated gender dummy coefficients at the $5^{\text {th }}, 10^{\text {th }}, 25^{\text {th }}, 50^{\text {th }}$, $75^{\text {th }}, 90^{\text {th }}$, and $95^{\text {th }}$ percentiles using the pooled 1998 data. We also present the corresponding estimated gender dummy coefficients from OLS regressions for comparison. The first panel shows the raw gender gap without any control variables. The coefficient estimates for the gender dummy in this panel are (necessarily) identical to the $\log$ wage gaps one could read off Figure 1. The advantage of quantile regression in this context is that we can attach standard errors to the estimated gender gaps at the various percentiles. As we saw in Figure 1, the gender gap increases as we move up the wage distribution with a particular acceleration after the $75^{\text {th }}$ percentile. We tested pairwise equality of adjacent coefficients (e.g., equality of the gender dummy coefficients at the $5^{\text {th }}$ and $10^{\text {th }}$ percentiles) and carried out an F-test for equality of all 7 gender dummy coefficients. The hypothesis of equality is overwhelmingly rejected (that is, $p$-value $\approx 0$ ) 
in all cases. Of course, this strengthens the point illustrated by Figure 1, namely, that just looking at the average gender gap ( $16.2 \%$-- the OLS estimate) is inadequate.

Panel 2 in Table 2 presents quantile regression estimates of the gender dummy coefficient when age, age-squared, the basic education variables (that is, Ed1-Ed7), and an immigrant dummy are added as controls. We begin with these basic regressors for two reasons. First, age (at least when a direct measure of experience is unavailable) and education are the two variables that are universally used in log wage regressions. Second, these variables and immigrant status, unlike other variables such as field of education, sector, industry, and occupation, are clearly exogenous.

The gender dummies in these regressions are interpreted as the effects of gender on log wage at the various percentiles once we control for individual differences in these basic labor market characteristics. Interestingly, when we control for age, education, and immigrant status, the gender dummies increase in absolute value relative to the raw gender dummies from the $5^{\text {th }}$ through the $75^{\text {th }}$ percentile. The OLS gender dummy coefficient also increases. One reason is that in the 1998 data, except at the top levels (that is, Ed6 and Ed7), women were better educated than men. In addition, all else equal, immigrants are paid less than nonimmigrant workers, and working women are less likely to be immigrants than are working men. At the $90^{\text {th }}$ and $95^{\text {th }}$ percentiles, however, controlling for the basic regressors decreases the effect of gender.

We present the complete set of coefficient estimates for the quantile regressions on the basic control variables in Table A2 in the appendix. The effect of age and age-squared on the log wage is constant in the bottom half of the distribution, but at the $75^{\text {th }}$ percentile and beyond, this effect increases. At almost every percentile, the estimated returns to education increase with level of education, and at each level of education, estimated returns increase almost uniformly by percentile. Finally, the effect of immigrant status decreases slightly as we move up the log wage distribution.

Because we know from the literature that gender differentials in work experience and tenure have significant power in explaining the gender gap, ${ }_{\text {we }}$ wse the fact that the 1991 SLLS data contain these variables as well as age by estimating our basic model

\footnotetext{
${ }^{14}$ Using 1988 U.S. data, Blau and Kahn (2000) report that 33 percent of the total gender gap could be explained by education, experience and race. Experience accounted for virtually all of the explained portion.
} 
using the 1991 data and then reestimating it using experience and tenure instead of age. The results from both estimations are presented in Appendix Table A3. Using age and age squared, the 1991 results are similar to those obtained using the 1998 data. Although all the estimated gender dummy coefficients are larger using the 1991 data, the unexplained gender gap still increases by percentile and accelerates at the $75^{\text {th }}$ percentile, just as in the 1998 estimates. Using the 1991 data, the estimated OLS gender dummy coefficient is 19.6 percent, with a variation from 12.8 percent for the $5^{\text {th }}$ percentile to 30.2 percent for the $95^{\text {th }}$ percentile. When we replace age with experience and add tenure, the unexplained gender gaps are reduced, but the basic pattern remains. Using OLS, the estimated effect of gender is 18.2 percent, with a variation from 11.8 percent for the $10^{\text {th }}$ percentile to 27.8 percent for the $90^{\text {th }}$ percentile. (The figure at the $5^{\text {th }}$ percentile is $12.8 \%$ and that at the $95^{\text {th }}$ percentile is $26.2 \%$.)

We would ideally like to use the 1992 SSW data to see if there are differences in the estimates based on the two data sources (that is, the SLLS data versus the SSW data), but since the $1992 \mathrm{SSW}$ data do not contain an immigrant variable, we could not estimate our basic model using these data. Instead, to investigate the comparability issue, we estimated the basic model without the immigrant variable first using the 1991 SLLS and then using the 1992 SSW data. These estimates are presented in Appendix Table A4 and are roughly comparable. Naturally, the estimates using the 1991 data are less precise since that dataset is much smaller.

Returning to Table 2, we now add a series of control variables that are arguably endogenous. Nonetheless, as an accounting exercise, it is useful to know the extent to which the gender gap at different percentiles can be "explained" by these variables. We first add field of education to the control variables, even though gender differences in choice of field of education may result from different labor market expectations. Using U.S. data, Brown and Corcoran (1997) show that a significant part of the average gender gap among college graduates is accounted for by differences in field of highest degree. We know of no previous Swedish study that uses field of education to address the gender-gap issue.

Our data allow us to distinguish among at most 10 fields of education within each of the education levels 3-7 (see footnote 2); in all, the quantile regressions include 46 
combinations of field and level. In Panel 3 of Table 2 we report the estimated gender gaps when these 46 combinations of level and field of education as well as age, age squared, and immigrant status are used as controls. All the estimated gender dummy coefficients decrease, but those at the $90^{\text {th }}$ and $95^{\text {th }}$ percentiles fall the most. Despite these reductions, the glass-ceiling pattern remains in the estimated unexplained gender gaps.

In Panel 4 of Table 2, we add sector of employment (private, local government, with central government as the left-out category) to our control variables. 15 Since the choice of sector in which to work is typically made after education is completed, the argument for the endogeneity of this variable is even stronger. As with the other variables, controlling for sector has the greatest effect at the top of the wage distribution. The reason is that working in the private sector has a large payoff in the top of the wage distribution, and many more men than women work in the private sector. In Panel 5, we present the estimated gender dummy coefficients that remain when we also control for industry of employment, using 24 industry dummies. In contrast to the previous panels, the effect of controlling for industry is similar throughout the wage distribution. That is, with the exception of the $5^{\text {th }}$ and $95^{\text {th }}$ percentiles, the reductions in the unexplained gender gap are not very different as we move up the log wage distribution.

In terms of explaining the gender gap by differences in labor market characteristics between the genders, the essential message of the first 5 panels of Table 2 is quite clear. Except at the very top of the wage distribution, controlling for covariates does not account for much of the gap. Even at the $75^{\text {th }}$ percentile, and even when we include variables that are arguably endogenous, we can explain less than $30 \%$ of the raw gender gap $(19.8 \%$ versus $13.8 \%)$. At the $90^{\text {th }}$ and $95^{\text {th }}$ percentiles, matters are somewhat different. Using only age, age-squared, and education, we can explain about $21 \%$ (respectively, 24\%) of the gender gap at the $90^{\text {th }}$ (respectively, $95^{\text {th }}$ ) percentiles. To put these figures in perspective, this is only slightly less than the fraction of the average gender gap that can be explained using OLS on the full set of covariates $(12.2 \%$ versus $16.2 \%)$. Once we include field of education, sector, and industry as regressors, we can reduce the coefficients on the gender dummy at the $90^{\text {th }}$ and $95^{\text {th }}$ percentiles even further,

\footnotetext{
${ }^{15}$ As indicated in Table 2, the number of observations used in the quantile regressions decreases when we add sector, because of missing data.
} 
but these coefficients are still considerably above those lower down in the distribution. In short, after adjusting for a set of basic control variables as well as field of education, sector, and industry, the gender gap is still greater at the top of the wage distribution than at the bottom.

The final panel of Table 2 examines the effect of gender differences in occupation. As indicated, for example, by Table 3 of Dolado et. al. (2001), the extent of occupational segregation in Sweden is greater than in the U.S. and the non-Scandinavian E.U. countries. This relatively segregated pattern might reflect a peculiarly Swedish preference that women work in family-friendly occupations -- although we think explanations based on cross-country differences in preferences are unconvincing --, it could reflect the rational response of workers and firms to the constraints and incentives implied by Swedish family policy, or it could simply be that occupations that are relatively segregated in other countries are particularly prevalent in Sweden. Whatever the factors underlying the relatively high degree of occupational segregation in Sweden, it is interesting to investigate the extent to which occupational differences account for the pattern that we see in the gender gap.

Meyersson-Milgrom et. al. (2001) also emphasize the occupational gender division in Sweden. They show that men and women with similar observable characteristics who have the same job with the same employer receive essentially the same wage. That is, the gender gap -- and specifically the glass ceiling effect -- primarily reflects the fact that men and women have different jobs. This is an important and useful fact, but we emphasize that we do not view occupational, or more generally job, segregation as an explanation of the glass ceiling effect. Occupation and wage are jointly determined variables. In this sense, occupational segregation is the form in which the glass ceiling is manifested rather than an independent explanation of it.

To examine the extent to which gender differences in occupation can account for the gender gap in wages, we use 107 occupational dummies. It was not feasible to run the quantile regressions with the 46 field of education dummies, the 24 industry dummies,

\footnotetext{
${ }^{16}$ In the sociological literature, occupational segregation is sometimes treated as a cause of the gender gap. For example, Wright et. al. (1999) have shown that the gender gap in workplace authority is higher in Sweden than in the United States. If, as suggested by Hultin and Szulkin (1999), the gender composition of
} 
and the 107 occupation dummies on the whole dataset. Instead, we took a sample of the dataset $(10 \%$ of the men and $10 \%$ of the women for whom we had information on occupation) and found that adding occupational dummies to the variables used in Panel 5 of Table 2 has a substantial effect. 1.7 The results are given in Panel 6 of Table 2. The unexplained gender gap falls to $8.4 \%$ at the $95^{\text {th }}$ percentile and to $3.8 \%$ at the $5^{\text {th }}$ percentile (compared to $18.5 \%$ at the $95^{\text {th }}$ percentile and to $4.8 \%$ at the $5^{\text {th }}$ percentile in Panel 5). That is, controlling for occupation substantially reduces the gender gap throughout the wage distribution. The effect of controlling for occupation on the gender gap reflects the occupational segregation that is present in Sweden It is interesting to note, however, that even when we include 107 occupation dummies, the gender gap is much larger at the top than at the bottom of the wage distribution.

The results presented in Table 2 assume that the coefficients on the explanatory variables are the same for men and women. In the next section, we examine whether this is in fact the case.

\section{B. Quantile Regressions by Gender}

Tables 3 and 4 present quantile log wage regressions by gender. In Table 3, we estimate the effects of age, age-squared and education on log wage separately for men and for women at the various percentiles. This table shows the extent to which returns to basic control variables differ between men and women at the various points in their respective distributions. In Table 4, we add two demographic variables, marital status and number of children, sector, and a dummy variable for full-time status. We do this because these variables are frequently mentioned as controls that have markedly different effects by gender. To save space, we only present results for the $10^{\text {th }}, 50^{\text {th }}$, and $90^{\text {th }}$ percentiles in Table 4. We discuss the results in Table 3 first.

The coefficients on age for men are always above the corresponding coefficients for women, and this gap grows as we move up the wage distribution. This is due in part to

the supervisory staff has an independent effect on wages, then occupational segregation could explain part of the observed pattern in the gender gap.

${ }^{17}$ As a check on the sampling procedure, we actually took 5 samples. The estimates presented in Panel 6 correspond to the sample among the 5 that produced the median gender gap estimated by OLS. The variation in the OLS and quantile regression estimates across the 5 samples is consistent with the estimated 
the fact that age is a better proxy for experience for men than it is for women and in part to the fact that women's log wage-experience profiles tend to be flatter than men's, even when a good measure of experience is available. In addition, the coefficient on age is higher for both men and women at the top of the wage distribution.

Women realize essentially the same return to education as men do at almost all levels of education at the very bottom of the wage distribution. Once we reach the $25^{\text {th }}$ percentile, men start to get a bigger payoff than women do at almost all levels of education. This is particularly true at the very top of the wage distribution. For some levels of education, this difference is quite important. For example, at the $95^{\text {th }}$ percentile in the two distributions, the payoff to a man who has completed at least three years of post-secondary schooling (Ed6) is estimated to be about 20\% higher (that is, 0.761-0.559) than the corresponding payoff to a woman. Interestingly, however, the payoffs to doctoral degrees (Ed7) do not seem to be much different between men and women. The immigrant penalty is greater for men than for women at all percentiles, and for both men and women the immigrant penalty falls almost uniformly as we move up the distribution.

The patterns for age, education, and immigrant status in Table 4 are similar. In terms of the additional variables, it is worth noting that being married has a positive effect for men and no significant effect for women and that number of children is almost always insignificant. ${ }_{18}$ The premium for working in the private sector is much higher for men than for women throughout the wage distribution, while the penalty associated with local government employment is greater for men at the bottom of the distribution but lower at the $90^{\text {th }}$ percentile. Working full time has a greater payoff for men than for women. This payoff is smaller at higher percentiles in the distribution and is in fact negative for women at the $90^{\text {th }}$ percentile.

Tables 3 and 4 clearly indicate that the returns to labor market variables are different for men and women. In discussing the results on the gender gaps presented in Table 2, we assumed that returns to characteristics were the same for men and women. In the next section, we look at the issue of whether the gender gap at various points in the wage

standard errors reported in Panel 6. For example, the coefficient estimates at the $5^{\text {th }}$ percentile range from .021 to -.043 , while the coefficient estimates at the $95^{\text {th }}$ percentile range from -.084 to -.104 . 
distribution is due to differences in labor market characteristics by gender or whether it is due to differences in the returns to these characteristics by gender.

\section{Decompositions}

In this section, we use quantile regression techniques to decompose the difference between the male and female log wage distributions into a component that is due to differences in labor market characteristics between the genders and a component that is due to differences in the rewards that the two genders receive for their labor market characteristics. This decomposition is in the spirit of the Oaxaca-Blinder technique (e.g., Oaxaca 1973) except that, rather than identifying the sources of the differences between the means of two distributions, we explain the differences, quantile by quantile, between the male and female log wage distributions.

There are several techniques available in the literature for decomposing differences in distributions. Probably the best known is the technique based on weighted-kernel estimates due to Dinardo, Fortin and Lemieux (1996). Other approaches include the hazard-based approach of Donald, Green and Paarsch (2000) and the rank regression method of Fortin and Lemieux (1998). We use an approach developed by Machado and Mata (2000), which is based on quantile regression techniques.

The idea is to generate two counterfactual densities: (i) the female log wage density that would arise if women were given men's labor market characteristics but continued to be "paid like women," and (ii) the density that would arise if women retained their own labor market characteristics but were "paid like men." The Machado-Mata approach to estimating the first density is as follows:

1. Draw n numbers at random from $(0,1)$, say $\theta_{1}, \theta_{2}, \ldots, \theta_{\mathrm{n}}$.

2. Using the female dataset, estimate the quantile regression coefficient vectors, $b^{f}\left(\theta_{i}\right)$, for $i=1, \ldots, n$.

3. Make $\mathrm{n}$ draws at random with replacement from the male dataset, denoted by $x_{i}^{m}$, for $\mathrm{i}=1, \ldots \mathrm{n}$.

\footnotetext{
${ }^{18}$ In the SSW data, the number of children (age 17 or younger) is defined as the number living with the adult in the sample. Using the 1991 SLLS data, we confirmed that our results were unaffected if we instead used the number of children the individual ever had.
} 
4. The counterfactual density is then generated as $\left\{\mathrm{y}_{\mathrm{i}}=x_{i}^{m} \mathrm{~b}^{\mathrm{f}}\left(\theta_{\mathrm{i}}\right)\right\}$ for $\mathrm{i}=1, \ldots, \mathrm{n}$. The approach to estimating the second counterfactual density (female characteristics, but "paid like men") is simply to reverse the roles of male and female in steps 2 and 3, that is, use the male dataset to estimate the quantile regression coefficients and make the bootstrap draws from the female dataset. Note, however, that the linearity of quantile regression implies that the decomposition of the difference between the male and female log wage densities is exact; that is,

$$
x^{m} b^{m}(\theta)-x^{f} b^{f}(\theta)=\left(x^{m}-x^{f}\right) b^{f}(\theta)+x^{m}\left(b^{m}(\theta)-b^{f}(\theta)\right) .
$$

We follow the Machado-Mata approach almost exactly, except that rather than drawing $n$ numbers at random from $(0,1)$ and then estimating $n$ quantile regression coefficient vectors, we simply estimate the quantile regressions at the first percentile, the second percentile, and so forth up to the $99^{\text {th }}$ percentile. Then, rather than taking one draw at random from the $\mathrm{X}$ matrix for each estimated coefficient vector, we make 100 draws for each $b\left(\theta_{i}\right)$. One can also use the Machado-Mata approach to estimate standard errors for the estimated counterfactual densities by repeating their procedure many times and generating a set of estimated densities. We do not estimate standard errors for our counterfactual densities. The number of observations in our dataset is such that repetition produces virtually identical estimated densities at each repetition.

The results from our decompositions are given in Table 5. The first panel of Table 5 gives the observed gender gaps at the various percentiles; that is, it is identical to the first panel of Table 2. The gender gaps reported in the rest of Table 5 are constructed by estimating the betas using only data on women and then assuming that women have the male distribution of labor market characteristics. For example, the second panel of Table 5 gives the gap between the male log wage density at various percentiles and the counterfactual density constructed assuming that women have the male distribution of age, education, and immigrant status, but are rewarded for these characteristics "like women."

It is interesting to compare these results with those in Table 2. Table 2 gives the gender gaps controlling for differences in labor market characteristics, but assuming that men and women receive the same rewards for these characteristics. The most striking difference between the two tables is at the top of the wage distribution. Whereas Table 2 
suggests that differences in characteristics account for a substantial portion of the gender gap at the top of the distribution, Table 5 indicates otherwise. In Table 5, when we control for age, education, and immigrant status (panel 2), the gender gap rises throughout the distribution. This indicates that it is clearly not gender differences in age, education, and immigrant status that account for the gender gap at the top of the distribution, but rather the differential rewards that women receive for these characteristics. The corresponding panel in Table 2 showed that controlling for these variables reduced the gender gap at the top by about one quarter, but this assumed, contrary to what we see in Tables 3 and 4, that the rewards that men and women receive for these characteristics are the same. The next three panels of Table 5 convey a similar message. Adding first field of education, then sector of employment, and then industry, reduces the gender gaps at the top of the distribution, but this effect is very small relative to that in Table 2. For example, after controlling for all these variables (Panel 5), the gender gap at the 95 th percentile falls from $38.7 \%$ to $31.0 \%$, while in Table 2 it falls to $18.5 \%$. (At the 90th percentile it falls to $31.7 \%$, whereas in Table 2 it falls to $16.8 \%$.) The results in Table 5 indicate that the glass ceiling effect is due to differences in rewards between the genders at the top of the wage distribution rather than to differences in characteristics.

It is interesting to perform this exercise on the $10 \%$ sample that was the basis of the estimates presented in Panel 6 of Table $2^{\frac{19}{1}}$. This is reported in the last panel of Table 5. Note that at the 95 th percentile the gap falls to $19.5 \%$ compared to the gender gap estimated controlling for occupation of $8.4 \%$ reported in Table 2. Table 5 shows that even after controlling for occupation there is a significant upward twist in the gender gap indicating evidence of a glass ceiling. This is even clearer in Figure 7 where the increased slope after the 75 th percentile is still evident even after including all the controls, that is, including occupation. We argued above that occupational segregation is the form in which the glass ceiling effect is manifested. What we see here is that even after taking occupation into account, there is a residual glass ceiling.

\footnotetext{
${ }^{19}$ As before, we also performed this exercise using the 4 other samples. In no case were the results qualitatively different.
} 


\section{Conclusions}

In this paper, we have addressed the question of whether there is a significant glass ceiling in Sweden. The answer, quite simply, is yes. There is an extremely large gap between men and women at the top of the wage distribution. The size of this gap is especially striking given the fact that the average gender gap in Sweden is quite small by international standards. It is also the case that this glass ceiling phenomenon is not diminishing over time - on the contrary, we find that the glass ceiling is much more pronounced in the 1990's than it was earlier. We also find that the glass ceiling is much more important in Sweden than in the U.S., which is perhaps contrary to what one might expect given the fact that the Swedish average log wage gap between the genders is smaller than the corresponding U.S. gap. Finally, we examine the log wage gap for nonimmigrants versus immigrants. The fact that this gap does not increase as we move up the wage distribution suggests that the glass ceiling effect is specifically related to gender, as opposed being to a more general labor market phenomenon.

We next examine the extent to which the gender gap at various percentiles in the wage distribution can be explained by differences in the characteristics that men and women bring to the labor market. Using quantile regressions that impose the restriction that the male and female coefficients are the same, we find that covariates can account for some of the gap between men and women, especially at the top of the wage distribution. Using the basic control variables reduces the gap at the $90^{\text {th }}$ and $95^{\text {th }}$ percentiles, but increases it further down in the wage distribution. Adding field of education, sector, and industry reduces the gender gaps found with the basic controls throughout the distribution. These latter variables are, however, arguably endogenous. When we also account for occupation, we find that the gender gap at the top of the distribution falls substantially. With our full set of controls, we are able to "account for" about three quarters of the gender gap at the top of the distribution. We argue, however, that including occupation, which accounts for about one-third of the "explained" gender gap at the top of the distribution, is really another way of showing the glass ceiling effect, which manifests itself partly through occupational segregation.

We also estimate separate quantile regressions by gender and find substantial differences between the genders in the coefficients on the covariates at various 
percentiles in the male and female distributions. This indicates that the pooled quantile regression results are misleading. Accordingly, we carry out a decomposition analysis to determine the extent to which the gender gap at various percentiles can be ascribed to differences between the genders in covariates versus differences in rewards to those covariates. This analysis shows that when we control for gender differences in basic covariates, age, education, and immigrant status, by giving women the labor market characteristics that men have, but allowing them "to be paid like women," we explain none of the gender gap at the top of the wage distribution. In fact, the gender gap increases throughout the distribution. Adjusting for field of education, sector, and industry explains a small portion of the gender gap, but gender differences in rewards to these characteristics are the more important factor. When we add occupation, the gender gap increases at the bottom of the distribution and decreases in the top three-quarters of the distribution. In fact, at the top of the distribution, the counterfactual gap falls to about half of the raw gender gap at the top. That is, about half of the gender gap at the top of the distribution is due to gender differences in rewards to labor market characteristics and about half to gender differences in the characteristics themselves. We emphasize again that we view gender differences in occupation as accounting for rather than explaining the gender gap, but it is interesting that the glass ceiling effect persists even after controlling for occupation.

Given the existence of a substantial glass ceiling effect in Sweden, it is tempting to speculate about possible causes. We have identified gender differences in rewards as a primary factor responsible for the glass ceiling effect, even when we account for occupation. This implies that a taste-based explanation, that is, that Swedish women prefer to work in family-friendly but low-wage jobs, is not consistent with our findings. In any case, we see no obvious reason why women in Sweden should have different preferences than, for example, women in the United States. It seems more fruitful to look for explanations in the work environment faced by Swedish women. In this regard, the obvious candidate is the collection of policies in Sweden that influence the interaction between work and family. Specifically, we have in mind Swedish parental leave policy and the daycare system. These policies give Swedish women (and men, in principle) a strong incentive to participate in the labor force. The benefits that a new parent can obtain 
when a child is born are strongly conditioned on that parent's employment history, and access to the daycare system is (essentially) conditioned on labor force participation. At the same time, the benefits may discourage strong career commitment on the part of the parents who are most involved in child rearing. In practice, this means that women may have strong incentives to participate in the labor force but not to do so very intensively. This policy effect may be compounded by employers, who presumably expect less career commitment from their female employees. Another factor may be that the relatively high wages at the bottom of the wage distribution make it very difficult for career-oriented women to hire household help or help with child care. ${ }^{20}$ As a result, women may choose (or be tracked into) the less demanding jobs. The outcome would then be one in which women do well relative to men at the bottom and middle of the wage distribution but fall substantially behind at the top of the distribution.

\footnotetext{
${ }^{20}$ Although Sweden has an extensive day-care (dagis) system, it is extremely unusual that a child can enter dagis before the age of 18 months.
} 
Table 1. Sample Means. Standard deviations in parentheses

\begin{tabular}{|c|c|c|c|c|c|c|c|c|c|c|}
\hline & \multicolumn{2}{|c|}{ SLLS-1968 } & \multicolumn{2}{|c|}{ SLLS-1981 } & \multicolumn{2}{|c|}{ SLLS-1991 } & \multicolumn{2}{|c|}{ SSW-1992 } & \multicolumn{2}{|c|}{ SSW-1998 } \\
\hline & Men & Women & Men & Women & Men & Women & Men & Women & Men & Women \\
\hline Ln wage & $\begin{array}{c}2.41 \\
(0.442)\end{array}$ & $\begin{array}{c}2.08 \\
(0.470)\end{array}$ & $\begin{array}{c}3.66 \\
(0.308)\end{array}$ & $\begin{array}{c}3.48 \\
(0.276)\end{array}$ & $\begin{array}{c}4.44 \\
(0.312)\end{array}$ & $\begin{array}{c}4.24 \\
(0.241)\end{array}$ & $\begin{array}{c}9.64 \\
(0.282)\end{array}$ & $\begin{array}{c}9.49 \\
(0.196)\end{array}$ & $\begin{array}{c}9.87 \\
(0.320)\end{array}$ & $\begin{array}{c}9.71 \\
(0.223)\end{array}$ \\
\hline P90/P10 & 2.59 & 2.46 & 1.97 & 1.65 & 2.05 & 1.71 & 1.96 & 1.56 & 2.13 & 1.63 \\
\hline $\mathrm{P} 90 / \mathrm{P} 50$ & 1.73 & 1.63 & 1.63 & 1.34 & 1.54 & 1.38 & 1.55 & 1.32 & 1.65 & 1.35 \\
\hline $\mathrm{P} 50 / \mathrm{P} 10$ & 1.50 & 1.51 & 1.28 & 1.23 & 1.33 & 1.24 & 1.26 & 1.18 & 1.29 & 1.21 \\
\hline Age & $\begin{array}{c}39.9 \\
(14.2)\end{array}$ & $\begin{array}{c}38.4 \\
(14.0)\end{array}$ & $\begin{array}{c}39.2 \\
(12.7)\end{array}$ & $\begin{array}{c}38.6 \\
(12.3)\end{array}$ & $\begin{array}{c}39.7 \\
(12.1)\end{array}$ & $\begin{array}{c}39.6 \\
(12.1)\end{array}$ & $\begin{array}{c}40.1 \\
(11.7)\end{array}$ & $\begin{array}{c}41.1 \\
(11.6)\end{array}$ & $\begin{array}{c}41.1 \\
(11.8)\end{array}$ & $\begin{array}{c}41.9 \\
(11.6)\end{array}$ \\
\hline $\begin{array}{l}\text { Years of } \\
\text { work exp. }\end{array}$ & $\begin{array}{c}23.0 \\
(15.0)\end{array}$ & $\begin{array}{c}14.7 \\
(11.8)\end{array}$ & $\begin{array}{c}20.6 \\
(13.8)\end{array}$ & $\begin{array}{c}15.4 \\
(10.9)\end{array}$ & $\begin{array}{c}20.1 \\
(13.0)\end{array}$ & $\begin{array}{c}16.8 \\
(10.8)\end{array}$ & n.a. & n.a. & n.a. & n.a. \\
\hline $\begin{array}{l}\text { Years of } \\
\text { schooling }\end{array}$ & $\begin{array}{c}8.63 \\
(2.92)\end{array}$ & $\begin{array}{c}8.66 \\
(2.69)\end{array}$ & $\begin{array}{c}10.7 \\
(3.59)\end{array}$ & $\begin{array}{c}10.3 \\
(3.15)\end{array}$ & $\begin{array}{c}11.7 \\
(3.33)\end{array}$ & $\begin{array}{c}11.5 \\
(2.91)\end{array}$ & n.a. & n.a. & n.a. & n.a. \\
\hline $\begin{array}{l}\text { Private } \\
\text { sector }\end{array}$ & $\begin{array}{c}0.762 \\
(0.426)\end{array}$ & $\begin{array}{c}0.559 \\
(0.497)\end{array}$ & $\begin{array}{c}0.702 \\
(0.457)\end{array}$ & $\begin{array}{c}0.402 \\
(0.491)\end{array}$ & $\begin{array}{c}0.705 \\
(0.456)\end{array}$ & $\begin{array}{c}0.388 \\
(0.488)\end{array}$ & $\begin{array}{c}0.733 \\
(0.442)\end{array}$ & $\begin{array}{c}0.395 \\
(0.489)\end{array}$ & $\begin{array}{c}0.720 \\
(0.449)\end{array}$ & $\begin{array}{c}0.393 \\
(0.488)\end{array}$ \\
\hline Ed1 & n.a. & n.a. & n.a. & n.a. & $\begin{array}{c}0.141 \\
(0.349)\end{array}$ & $\begin{array}{c}0.111 \\
(0.314)\end{array}$ & $\begin{array}{c}0.143 \\
(0.351)\end{array}$ & $\begin{array}{c}0.120 \\
(0.324)\end{array}$ & $\begin{array}{c}0.088 \\
(0.283)\end{array}$ & $\begin{array}{c}0.064 \\
(0.249)\end{array}$ \\
\hline Ed2 & n.a. & n.a. & n.a. & n.a. & $\begin{array}{c}0.110 \\
(0.313) \\
\end{array}$ & $\begin{array}{c}0.117 \\
(0.321) \\
\end{array}$ & $\begin{array}{c}0.116 \\
(0.320) \\
\end{array}$ & $\begin{array}{c}0.114 \\
(0.318) \\
\end{array}$ & $\begin{array}{c}0.119 \\
(0.324) \\
\end{array}$ & $\begin{array}{c}0.103 \\
(0.304) \\
\end{array}$ \\
\hline Ed3 & n.a. & n.a. & n.a. & n.a. & $\begin{array}{c}0.358 \\
(0.479) \\
\end{array}$ & $\begin{array}{c}0.409 \\
(0.492) \\
\end{array}$ & $\begin{array}{c}0.334 \\
(0.472) \\
\end{array}$ & $\begin{array}{c}0.383 \\
(0.486) \\
\end{array}$ & $\begin{array}{c}0.317 \\
(0.465) \\
\end{array}$ & $\begin{array}{c}0.350 \\
(0.477) \\
\end{array}$ \\
\hline Ed4 & n.a. & n.a. & n.a. & n.a. & $\begin{array}{c}0.153 \\
(0.360)\end{array}$ & $\begin{array}{c}0.116 \\
(0.320)\end{array}$ & $\begin{array}{c}0.146 \\
(0.354)\end{array}$ & $\begin{array}{c}0.106 \\
(0.308)\end{array}$ & $\begin{array}{c}0.190 \\
(0.392)\end{array}$ & $\begin{array}{c}0.148 \\
(.0 .355)\end{array}$ \\
\hline$\overline{E d 5}$ & n.a. & n.a. & n.a. & n.a. & $\begin{array}{c}0.116 \\
(0.320)\end{array}$ & $\begin{array}{c}0.136 \\
(0.343)\end{array}$ & $\begin{array}{c}0.129 \\
(0.336)\end{array}$ & $\begin{array}{c}0.153 \\
(0.360)\end{array}$ & $\begin{array}{c}0.140 \\
(0.347)\end{array}$ & $\begin{array}{c}0.176 \\
(0.381)\end{array}$ \\
\hline Ed6 & n.a. & n.a. & n.a. & n.a. & $\begin{array}{c}0.108 \\
(0.310)\end{array}$ & $\begin{array}{c}0.108 \\
(0.311)\end{array}$ & $\begin{array}{c}0.120 \\
(0.325)\end{array}$ & $\begin{array}{c}0.122 \\
(0.327)\end{array}$ & $\begin{array}{c}0.132 \\
(0.339)\end{array}$ & $\begin{array}{c}0.153 \\
(0.360)\end{array}$ \\
\hline Ed7 & n.a. & n.a. & n.a. & n.a. & $\begin{array}{c}0.015 \\
(0.120)\end{array}$ & $\begin{array}{c}0.004 \\
(0.060)\end{array}$ & $\begin{array}{c}0.011 \\
(0.105)\end{array}$ & $\begin{array}{c}0.003 \\
(0.055)\end{array}$ & $\begin{array}{c}0.013 \\
(0.113)\end{array}$ & $\begin{array}{c}0.005 \\
(0.069)\end{array}$ \\
\hline \# of obs & 1894 & 1191 & 1822 & 1659 & 1655 & 1663 & 14266 & 15015 & 49780 & 48407 \\
\hline
\end{tabular}


Table 2

Overview of Estimated Gender Gaps Using Alternative Models, 1998

\begin{tabular}{|c|c|c|c|c|c|c|c|}
\hline$\stackrel{\text { 5th }}{\text { Percentile }}$ & $\frac{10^{\text {th }}}{\text { Percentile }}$ & $\underline{\underline{25^{\text {th }}}}$ & $\frac{50^{\text {th }}}{\text { Percentile }}$ & Percentile & $\begin{array}{c}\frac{90^{\text {th }}}{\text { Percentile }} \\
\underline{\underline{n}}\end{array}$ & $\begin{array}{c}{ }^{95^{\text {th }}} \\
\text { Percentile }\end{array}$ & $\underline{\text { OLS }}$ \\
\hline \multicolumn{8}{|c|}{$\begin{array}{l}\text { 1. Observed Gender Gap } \\
\qquad \mathrm{n}=98200\end{array}$} \\
\hline $\begin{array}{l}-. .048 \\
(.0025)\end{array}$ & $\begin{array}{l}-. .065 \\
(.0013)\end{array}$ & $\begin{array}{l}-. .098 \\
(.0016)\end{array}$ & $\begin{array}{l}-.133 \\
(.0017)\end{array}$ & $\begin{array}{l}-.198 \\
(.0031)\end{array}$ & $\begin{array}{l}-.336 \\
(.0029)\end{array}$ & $\begin{array}{l}-.387 \\
(.0073)\end{array}$ & $\begin{array}{l}-.162 \\
(.0018)\end{array}$ \\
\hline \multicolumn{8}{|c|}{$\begin{array}{l}\text { 2. Gender Gap with Basic Control Variables } \\
\qquad \mathrm{n}=98200\end{array}$} \\
\hline $\begin{array}{l}-.059 \\
(.0021)\end{array}$ & $\begin{array}{l}-. .079 \\
(.0014)\end{array}$ & $\begin{array}{l}-.115 \\
(.0012)\end{array}$ & $\begin{array}{l}-.158 \\
(.0013)\end{array}$ & $\begin{array}{l}-.211 \\
(.0022)\end{array}$ & $\begin{array}{l}-.266 \\
(.0032)\end{array}$ & $\begin{array}{l}-.293 \\
(.0046)\end{array}$ & $\begin{array}{l}-.174 \\
(.0015)\end{array}$ \\
\hline \multicolumn{8}{|c|}{$\begin{array}{l}\text { 3. Gender Gap with Basic Control Variables and Field of Education } \\
\qquad \mathrm{n}=98200\end{array}$} \\
\hline $\begin{array}{l}-. .053 \\
(.0026)\end{array}$ & $\begin{array}{l}-. .069 \\
(.0016)\end{array}$ & $\begin{array}{ll}-.100 \\
(.0014)\end{array}$ & $\begin{array}{l}-.134 \\
(.0017)\end{array}$ & $\begin{array}{l}-.177 \\
(.0021)\end{array}$ & $\begin{array}{l}-.221 \\
(.0033)\end{array}$ & $\begin{array}{l}-.254 \\
(.0053)\end{array}$ & $\begin{array}{l}-.153 \\
(.0017)\end{array}$ \\
\hline \multicolumn{8}{|c|}{$\begin{array}{l}\text { 4. Gender Gap with Basic Control Variables, Field of Education, and Sector } \\
\qquad \mathrm{n}=98187\end{array}$} \\
\hline $\begin{array}{c}-.050 \\
(.0027)\end{array}$ & $\begin{array}{c}-.065 \\
(.0018) \\
\end{array}$ & $\begin{array}{c}-.085 \\
(.0014) \\
\end{array}$ & $\begin{array}{c}-.113 \\
(.0014) \\
\end{array}$ & $\begin{array}{c}-.150 \\
(.0021) \\
\end{array}$ & $\begin{array}{c}-.180 \\
(.0032)\end{array}$ & $\begin{array}{c}-.206 \\
(.0049) \\
\end{array}$ & $\begin{array}{c}-.132 \\
(.0017) \\
\end{array}$ \\
\hline \multicolumn{8}{|c|}{$\begin{array}{l}\text { 5. Gender Gap with Basic Control Variables, Field of Education, Sector, and Industry } \\
\qquad \mathrm{n}=98187\end{array}$} \\
\hline $\begin{array}{l}-. .048 \\
(.0025)\end{array}$ & $\begin{array}{l}-. .055 \\
(.0018)\end{array}$ & $\begin{array}{l}-. .071 \\
(.0013)\end{array}$ & $\begin{array}{ll}-.101 \\
(.0014)\end{array}$ & $\begin{array}{l}-.138 \\
(.0021)\end{array}$ & $\begin{array}{l}-.168 \\
(.0032)\end{array}$ & $\begin{array}{l}-.185 \\
(.0048)\end{array}$ & $\begin{array}{l}-.122 \\
(.0017)\end{array}$ \\
\hline \multicolumn{8}{|c|}{$\begin{array}{l}\text { 6. Gender Gap with Basic Controls, Field of Education, Sector, Industry, and Occupation } \\
\text { Using } 10 \% \text { Sample }-\mathrm{n}=9611^{\frac{12}{2}}\end{array}$} \\
\hline $\begin{array}{l}-. .038 \\
(.0096)\end{array}$ & $\begin{array}{ll}-.040 \\
(.0060)\end{array}$ & $\begin{array}{l}-.053 \\
(.0062)\end{array}$ & $\begin{array}{ll}-.065 \\
(.0032)\end{array}$ & $\begin{array}{l}-.083 \\
(.0076)\end{array}$ & $\begin{array}{ll}-.080 \\
(.0099)\end{array}$ & $\begin{array}{l}-.084 \\
(.0086)\end{array}$ & $\begin{array}{l}-.076 \\
(.0053)\end{array}$ \\
\hline
\end{tabular}

\footnotetext{
${ }^{21}$ The sample was constructed by taking $10 \%$ of the women and $10 \%$ of the men for whom information on occupation was available. This gave 4856 men and 4755 women.
} 
Table 3. Quantile Regressions By Gender: Standard Errors in Parentheses, 1998

\begin{tabular}{|c|c|c|c|c|c|c|c|c|}
\hline & $\frac{5^{\text {th }}}{\text { Percentile }}$ & $\frac{10^{\text {th }}}{\text { Percentile }}$ & $\begin{array}{c}25^{\text {th }} \\
\text { Percentile }\end{array}$ & $\begin{array}{c}50^{\text {th }} \\
\text { Percentile }\end{array}$ & $\frac{75^{\text {th }}}{\text { Percentile }}$ & $\begin{array}{c}90^{\text {th }} \\
\text { Percentile }\end{array}$ & $\begin{array}{c}95^{\text {th }} \\
\text { Percentile }\end{array}$ & $\underline{\text { OLS }}$ \\
\hline \multicolumn{9}{|c|}{$\begin{array}{c}\text { Men } \\
(\mathrm{n}=49788)\end{array}$} \\
\hline Age & $\begin{array}{c}.031 \\
(.0012)\end{array}$ & $\begin{array}{c}.030 \\
(.0009)\end{array}$ & $\begin{array}{c}.029 \\
(.0007)\end{array}$ & $\begin{array}{c}.032 \\
(.0007)\end{array}$ & $\begin{array}{c}.035 \\
(.0011)\end{array}$ & $\begin{array}{c}.046 \\
(.0019)\end{array}$ & $\begin{array}{c}.051 \\
(.0026)\end{array}$ & $\begin{array}{c}.036 \\
(.0008)\end{array}$ \\
\hline $\begin{array}{l}\text { Age } \\
\text { Sq/100 }\end{array}$ & $\begin{array}{c}-.031 \\
(.0015)\end{array}$ & $\begin{array}{l}-.030 \\
(.0011)\end{array}$ & $\begin{array}{c}-.028 \\
(.0009)\end{array}$ & $\begin{array}{c}-.031 \\
(.0009)\end{array}$ & $\begin{array}{c}-.032 \\
(.0013)\end{array}$ & $\begin{array}{c}-.043 \\
(.0023)\end{array}$ & $\begin{array}{c}-.047 \\
(.0032)\end{array}$ & $\begin{array}{c}-.034 \\
(.0009)\end{array}$ \\
\hline$\overline{E d} 2$ & $\begin{array}{c}-.003 \\
(.0081)\end{array}$ & $\begin{array}{c}.007 \\
(.0062)\end{array}$ & $\begin{array}{c}.036 \\
(.0049)\end{array}$ & $\begin{array}{c}.057 \\
(.0052)\end{array}$ & $\begin{array}{c}.106 \\
(.0079)\end{array}$ & $\begin{array}{c}.160 \\
(.0131)\end{array}$ & $\begin{array}{c}.219 \\
(.0184)\end{array}$ & $\begin{array}{c}.076 \\
(.0057)\end{array}$ \\
\hline Ed3 & $\begin{array}{c}.041 \\
(.0072)\end{array}$ & $\begin{array}{c}.048 \\
(.0055)\end{array}$ & $\begin{array}{c}.071 \\
(.0043)\end{array}$ & $\begin{array}{c}.090 \\
(.0046)\end{array}$ & $\begin{array}{c}.128 \\
(.0069)\end{array}$ & $\begin{array}{c}.169 \\
(.0114)\end{array}$ & $\begin{array}{c}.216 \\
(.0160)\end{array}$ & $\begin{array}{c}.104 \\
(.0050)\end{array}$ \\
\hline Ed4 & $\begin{array}{c}.055 \\
(.0073)\end{array}$ & $\begin{array}{c}.069 \\
(.0056)\end{array}$ & $\begin{array}{c}.109 \\
(.0044)\end{array}$ & $\begin{array}{c}.154 \\
(.0048)\end{array}$ & $\begin{array}{c}.248 \\
(.0074)\end{array}$ & $\begin{array}{c}.337 \\
(.0122)\end{array}$ & $\begin{array}{c}.406 \\
(.0172)\end{array}$ & $\begin{array}{c}.197 \\
(.0052)\end{array}$ \\
\hline Ed5 & $\begin{array}{c}.117 \\
(.0079)\end{array}$ & $\begin{array}{c}.139 \\
(.0060)\end{array}$ & $\begin{array}{c}.194 \\
(.0047)\end{array}$ & $\begin{array}{c}.243 \\
(.0051)\end{array}$ & $\begin{array}{c}.329 \\
(.0077)\end{array}$ & $\begin{array}{c}.431 \\
(.0128)\end{array}$ & $\begin{array}{c}.491 \\
(.0179)\end{array}$ & $\begin{array}{c}.276 \\
(.0055)\end{array}$ \\
\hline Ed6 & $\begin{array}{c}.199 \\
(.0077)\end{array}$ & $\begin{array}{c}.228 \\
(.0058)\end{array}$ & $\begin{array}{c}.287 \\
(.0046)\end{array}$ & $\begin{array}{c}.419 \\
(.0050)\end{array}$ & $\begin{array}{c}.606 \\
(.0076)\end{array}$ & $\begin{array}{c}.698 \\
(.0125)\end{array}$ & $\begin{array}{c}.761 \\
(.0176)\end{array}$ & $\begin{array}{c}.455 \\
(.0055)\end{array}$ \\
\hline$\overline{E d 7}$ & $\begin{array}{c}.366 \\
(.0158)\end{array}$ & $\begin{array}{c}.404 \\
(.0121)\end{array}$ & $\begin{array}{c}.493 \\
(.0096)\end{array}$ & $\begin{array}{c}.589 \\
(.0104)\end{array}$ & $\begin{array}{c}.722 \\
(.0157)\end{array}$ & $\begin{array}{c}.794 \\
(.0258)\end{array}$ & $\begin{array}{c}.806 \\
(.0359)\end{array}$ & $\begin{array}{c}.608 \\
(.0113)\end{array}$ \\
\hline Imm & $\begin{array}{c}-.185 \\
(.0111)\end{array}$ & $\begin{array}{l}-.168 \\
(.0086)\end{array}$ & $\begin{array}{l}-.161 \\
(.0067)\end{array}$ & $\begin{array}{c}-.149 \\
(.0073)\end{array}$ & $\begin{array}{c}-.129 \\
(.0110)\end{array}$ & $\begin{array}{c}.125 \\
(.0180)\end{array}$ & $\begin{array}{c}.123 \\
(.0252)\end{array}$ & $\begin{array}{c}-.161 \\
(.0080)\end{array}$ \\
\hline Constant & $\begin{array}{c}8.763 \\
(.0243)\end{array}$ & $\begin{array}{c}8.821 \\
(.0185)\end{array}$ & $\begin{array}{c}8.908 \\
(.0140)\end{array}$ & $\begin{array}{c}8.929 \\
(.0146)\end{array}$ & $\begin{array}{c}8.921 \\
(.0217)\end{array}$ & $\begin{array}{c}8.778 \\
(.0363)\end{array}$ & $\begin{array}{c}8.727 \\
(.0509)\end{array}$ & $\begin{array}{c}8.834 \\
(.0159)\end{array}$ \\
\hline \multicolumn{9}{|c|}{$\begin{array}{c}\text { Women } \\
(\mathrm{n}=48412)\end{array}$} \\
\hline Age & $\begin{array}{c}.023 \\
(.0009)\end{array}$ & $\begin{array}{c}.023 \\
(.0006)\end{array}$ & $\begin{array}{c}.022 \\
(.0004)\end{array}$ & $\begin{array}{c}.020 \\
(.0005)\end{array}$ & $\begin{array}{c}.023 \\
(.0008)\end{array}$ & $\begin{array}{c}.027 \\
(.0014)\end{array}$ & $\begin{array}{c}.032 \\
(.0022)\end{array}$ & $\begin{array}{c}.024 \\
(.0006)\end{array}$ \\
\hline $\begin{array}{l}\text { Age } \\
\text { Sq/100 }\end{array}$ & $\begin{array}{c}-.023 \\
(.0010)\end{array}$ & $\begin{array}{c}-.023 \\
(.0007)\end{array}$ & $\begin{array}{c}-.021 \\
(.0005)\end{array}$ & $\begin{array}{c}-.019 \\
(.0006)\end{array}$ & $\begin{array}{c}-.023 \\
(.0009)\end{array}$ & $\begin{array}{c}-.028 \\
(.0017)\end{array}$ & $\begin{array}{c}-.033 \\
(.0026)\end{array}$ & $\begin{array}{c}.024 \\
(.0007)\end{array}$ \\
\hline$\overline{E d} 2$ & $\begin{array}{c}.016 \\
(.0064)\end{array}$ & $\begin{array}{c}.019 \\
(.0045)\end{array}$ & $\begin{array}{c}.036 \\
(.0034)\end{array}$ & $\begin{array}{c}.058 \\
(.0038)\end{array}$ & $\begin{array}{c}.071 \\
(.0063)\end{array}$ & $\begin{array}{c}.095 \\
(.0111)\end{array}$ & $\begin{array}{c}.118 \\
(.0172)\end{array}$ & $\begin{array}{c}.061 \\
(.0045)\end{array}$ \\
\hline Ed3 & $\begin{array}{c}.053 \\
(.0056) \\
\end{array}$ & $\begin{array}{c}.050 \\
(.0040) \\
\end{array}$ & $\begin{array}{c}.061 \\
(.0030) \\
\end{array}$ & $\begin{array}{c}.072 \\
(.0033) \\
\end{array}$ & $\begin{array}{c}.068 \\
(.0054) \\
\end{array}$ & $\begin{array}{c}.069 \\
(.0096) \\
\end{array}$ & $\begin{array}{c}.070 \\
(.0148) \\
\end{array}$ & $\begin{array}{c}.069 \\
(.0039) \\
\end{array}$ \\
\hline$\overline{E d 4}$ & $\begin{array}{c}.064 \\
(.0063)\end{array}$ & $\begin{array}{c}.068 \\
(.0045)\end{array}$ & $\begin{array}{c}.096 \\
(.0034)\end{array}$ & $\begin{array}{c}.124 \\
(.0037)\end{array}$ & $\begin{array}{c}.140 \\
(.0062)\end{array}$ & $\begin{array}{c}.178 \\
(.0111)\end{array}$ & $\begin{array}{c}.221 \\
(.0172)\end{array}$ & $\begin{array}{c}.132 \\
(.0044)\end{array}$ \\
\hline Ed5 & $\begin{array}{c}.134 \\
(.0059)\end{array}$ & $\begin{array}{c}.141 \\
(.0042)\end{array}$ & $\begin{array}{c}.159 \\
(.0032)\end{array}$ & $\begin{array}{c}.186 \\
(.0035)\end{array}$ & $\begin{array}{c}.211 \\
(.0058)\end{array}$ & $\begin{array}{c}.241 \\
(.0104)\end{array}$ & $\begin{array}{c}.279 \\
(.0159)\end{array}$ & $\begin{array}{c}.193 \\
(.0041)\end{array}$ \\
\hline Ed6 & $\begin{array}{c}.218 \\
(.0059)\end{array}$ & $\begin{array}{c}.232 \\
(.0042)\end{array}$ & $\begin{array}{c}.270 \\
(.0032)\end{array}$ & $\begin{array}{c}.307 \\
(.0036) \\
\end{array}$ & $\begin{array}{c}.332 \\
(.0058)\end{array}$ & $\begin{array}{c}.458 \\
(.0104)\end{array}$ & $\begin{array}{c}.559 \\
(.0162) \\
\end{array}$ & $\begin{array}{c}.327 \\
(.0042) \\
\end{array}$ \\
\hline Ed7 & $\begin{array}{c}.334 \\
(.0180) \\
\end{array}$ & $\begin{array}{c}.411 \\
(.0130) \\
\end{array}$ & $\begin{array}{c}.479 \\
(.0098)\end{array}$ & $\begin{array}{c}.610 \\
(.0110)\end{array}$ & $\begin{array}{c}.688 \\
(.0180)\end{array}$ & $\begin{array}{c}.768 \\
(.0321)\end{array}$ & $\begin{array}{c}.801 \\
(.0487)\end{array}$ & $\begin{array}{c}.599 \\
(.0129)\end{array}$ \\
\hline Imm & $\begin{array}{l}-.130 \\
(.0084)\end{array}$ & $\begin{array}{c}-.127 \\
(.0060)\end{array}$ & $\begin{array}{c}-.102 \\
(.0045)\end{array}$ & $\begin{array}{l}.078 \\
(.0050)\end{array}$ & $\begin{array}{c}-.072 \\
(.0082)\end{array}$ & $\begin{array}{l}.082 \\
(.0147)\end{array}$ & $\begin{array}{c}.072 \\
(.0225)\end{array}$ & $\begin{array}{c}.092 \\
(.0059)\end{array}$ \\
\hline Constant & $\begin{array}{c}8.843 \\
(.0181)\end{array}$ & $\begin{array}{c}8.885 \\
(.0126)\end{array}$ & $\begin{array}{c}8.958 \\
(.0090)\end{array}$ & $\begin{array}{c}9.059 \\
(.0098)\end{array}$ & $\begin{array}{c}9.126 \\
(.0160)\end{array}$ & $\begin{array}{c}9.149 \\
(.0288)\end{array}$ & $\begin{array}{c}9.143 \\
(.0448)\end{array}$ & $\begin{array}{c}9.007 \\
(.0114)\end{array}$ \\
\hline
\end{tabular}


Table 4. Quantile Regressions By Gender: Standard Errors in Parentheses, 1998

\begin{tabular}{|c|c|c|c|c|c|c|c|c|}
\hline & \multicolumn{4}{|c|}{$\begin{array}{c}\text { Men } \\
(\mathrm{n}=49780)\end{array}$} & \multicolumn{4}{|c|}{$\begin{array}{c}\text { Women } \\
(\mathrm{n}=48407)\end{array}$} \\
\hline & $\frac{10^{\text {th }}}{\text { Percentile }}$ & $\frac{50^{\text {th }}}{\text { Percentile }}$ & 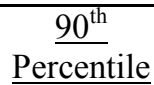 & $\underline{\text { OLS }}$ & $\frac{10^{\text {th }}}{\text { Percentile }}$ & $\frac{50^{\text {th }}}{\text { Percentile }}$ & $\begin{array}{c}90^{\text {th }} \\
\text { Percentile }\end{array}$ & $\underline{\text { OLS }}$ \\
\hline Age & $\begin{array}{c}.025 \\
(.0010)\end{array}$ & $\begin{array}{c}.028 \\
(.0009)\end{array}$ & $\begin{array}{c}.040 \\
(.0020)\end{array}$ & $\begin{array}{c}.031 \\
(.0009)\end{array}$ & $\begin{array}{c}.022 \\
(.0006)\end{array}$ & $\begin{array}{c}.021 \\
(.0005)\end{array}$ & $\begin{array}{c}.026 \\
(.0012)\end{array}$ & $\begin{array}{c}.025 \\
(.0006)\end{array}$ \\
\hline $\begin{array}{l}\text { Age } \\
\mathrm{Sq} / 100\end{array}$ & $\begin{array}{c}-.025 \\
(.0012)\end{array}$ & $\begin{array}{c}-.026 \\
(.0011)\end{array}$ & $\begin{array}{c}-.036 \\
(.0024)\end{array}$ & $\begin{array}{c}-.028 \\
(.0010)\end{array}$ & $\begin{array}{c}-.021 \\
(.0008)\end{array}$ & $\begin{array}{c}-.020 \\
(.0007)\end{array}$ & $\begin{array}{c}-.026 \\
(.0014)\end{array}$ & $\begin{array}{c}-.024 \\
(.0007)\end{array}$ \\
\hline$\overline{E d} 2$ & $\begin{array}{c}.015 \\
(.0059)\end{array}$ & $\begin{array}{l}.065 \\
(.0056\end{array}$ & $\begin{array}{l}.163 \\
(.0129)\end{array}$ & $\begin{array}{c}.084 \\
(.0055)\end{array}$ & $\begin{array}{c}.020 \\
(.0044)\end{array}$ & $\begin{array}{c}.058 \\
(.0039)\end{array}$ & $\begin{array}{c}.086 \\
(.0083)\end{array}$ & $\begin{array}{c}.065 \\
(.0043)\end{array}$ \\
\hline Ed3 & $\begin{array}{c}.054 \\
(.0053)\end{array}$ & $\begin{array}{c}.099 \\
(.0049)\end{array}$ & $\begin{array}{l}.182 \\
(.0112)\end{array}$ & $\begin{array}{c}.114 \\
(.0048)\end{array}$ & $\begin{array}{c}.047 \\
(.0038)\end{array}$ & $\begin{array}{c}.087 \\
(.0034)\end{array}$ & $\begin{array}{c}.109 \\
(.0073)\end{array}$ & $\begin{array}{c}.091 \\
(.0038)\end{array}$ \\
\hline Ed4 & $\begin{array}{c}.073 \\
(.0054)\end{array}$ & $\begin{array}{l}.172 \\
(.0051)\end{array}$ & $\begin{array}{c}.337 \\
(.0121)\end{array}$ & $\begin{array}{c}.207 \\
(.0050)\end{array}$ & $\begin{array}{c}.064 \\
(.0043)\end{array}$ & $\begin{array}{c}.121 \\
(.0038)\end{array}$ & $\begin{array}{c}.167 \\
(.0083)\end{array}$ & $\begin{array}{c}.133 \\
(.0043)\end{array}$ \\
\hline Ed5 & $\begin{array}{l}.158 \\
(.0058)\end{array}$ & $\begin{array}{c}.275 \\
(.0054)\end{array}$ & $\begin{array}{c}.435 \\
(.0129)\end{array}$ & $\begin{array}{c}.306 \\
(.0054)\end{array}$ & $\begin{array}{c}.133 \\
(.0041)\end{array}$ & $\begin{array}{c}.210 \\
(.0037)\end{array}$ & $\begin{array}{c}.287 \\
(.0081)\end{array}$ & $\begin{array}{c}.221 \\
(.0041)\end{array}$ \\
\hline Ed6 & $\begin{array}{l}.246 \\
(.0057)\end{array}$ & $\begin{array}{c}.456 \\
(.0054)\end{array}$ & $\begin{array}{c}.732 \\
(.0128)\end{array}$ & $\begin{array}{c}.500 \\
(.0054)\end{array}$ & $\begin{array}{c}.218 \\
(.0041)\end{array}$ & $\begin{array}{c}.334 \\
(.0037)\end{array}$ & $\begin{array}{c}.479 \\
(.0082)\end{array}$ & $\begin{array}{c}.358 \\
(.0041)\end{array}$ \\
\hline$\overline{E d 7}$ & $\begin{array}{c}.416 \\
(.0118)\end{array}$ & $\begin{array}{c}.633 \\
(.0112)\end{array}$ & $\begin{array}{c}.910 \\
(.0261)\end{array}$ & $\begin{array}{c}.665 \\
(.0110)\end{array}$ & $\begin{array}{c}.370 \\
(.0125)\end{array}$ & $\begin{array}{c}.604 \\
(.0113)\end{array}$ & $\begin{array}{c}.877 \\
(.0245)\end{array}$ & $\begin{array}{c}.602 \\
(.0125)\end{array}$ \\
\hline Married & $\begin{array}{c}.034 \\
(.0031)\end{array}$ & $\begin{array}{c}.048 \\
(.0030)\end{array}$ & $\begin{array}{c}.100 \\
(.0067)\end{array}$ & $\begin{array}{c}.064 \\
(.0029)\end{array}$ & $\begin{array}{c}.002 \\
(.0020)\end{array}$ & $\begin{array}{c}.001 \\
(.0018)\end{array}$ & $\begin{array}{c}-.006 \\
(.0039)\end{array}$ & $\begin{array}{c}.001 \\
(.0020)\end{array}$ \\
\hline $\begin{array}{l}\text { No. of } \\
\text { Children }\end{array}$ & $\begin{array}{c}.004 \\
(.0015)\end{array}$ & $\begin{array}{c}.002 \\
(.0014)\end{array}$ & $\begin{array}{l}-.005 \\
(.0032)\end{array}$ & $\begin{array}{c}.001 \\
(.0014)\end{array}$ & $\begin{array}{l}.002 \\
(.0011)\end{array}$ & $\begin{array}{l}-.003 \\
(.0010)\end{array}$ & $\begin{array}{c}.000 \\
(.0021)\end{array}$ & $\begin{array}{c}-.003 \\
(.0011)\end{array}$ \\
\hline Private & $\begin{array}{c}.009 \\
(.0038)\end{array}$ & $\begin{array}{c}.079 \\
(.0036)\end{array}$ & $\begin{array}{c}.155 \\
(.0087)\end{array}$ & $\begin{array}{c}.095 \\
(.0036)\end{array}$ & $\begin{array}{c}-.037 \\
(.0030)\end{array}$ & $\begin{array}{c}.021 \\
(.0027)\end{array}$ & $\begin{array}{c}.101 \\
(.0058)\end{array}$ & $\begin{array}{c}.029 \\
(.0030)\end{array}$ \\
\hline $\begin{array}{l}\text { Local } \\
\text { Gov. }\end{array}$ & $\begin{array}{l}-.056 \\
(.0048)\end{array}$ & $\begin{array}{l}-.077 \\
(.0045)\end{array}$ & $\begin{array}{l}-.073 \\
(.0103)\end{array}$ & $\begin{array}{c}.074 \\
(.0044)\end{array}$ & $\begin{array}{c}-.035 \\
(.0029)\end{array}$ & $\begin{array}{l}-.061 \\
(.0026)\end{array}$ & $\begin{array}{c}.114 \\
(.0056)\end{array}$ & $\begin{array}{c}.068 \\
(.0029)\end{array}$ \\
\hline $\begin{array}{l}\text { Full-Time } \\
\text { Dummy }\end{array}$ & $\begin{array}{l}.128 \\
(.0055)\end{array}$ & $\begin{array}{c}.099 \\
(.0051)\end{array}$ & $\begin{array}{c}.059 \\
(.0114)\end{array}$ & $\begin{array}{c}.109 \\
(.0050)\end{array}$ & $\begin{array}{c}.054 \\
(.0021)\end{array}$ & $\begin{array}{c}.028 \\
(.0019)\end{array}$ & $\begin{array}{c}.056 \\
(.0039)\end{array}$ & $\begin{array}{c}.026 \\
(.0021)\end{array}$ \\
\hline $\begin{array}{l}\text { Imm } \\
\text { Dummy }\end{array}$ & $\begin{array}{l}-.169 \\
(.0082)\end{array}$ & $\begin{array}{c}. .144 \\
(.0078)\end{array}$ & $\begin{array}{c}-.147 \\
(.0179)\end{array}$ & $\begin{array}{c}.168 \\
(.0077)\end{array}$ & $\begin{array}{l}-.112 \\
(.0057)\end{array}$ & $\begin{array}{l}-.075 \\
(.0051)\end{array}$ & $\begin{array}{c}-.066 \\
(.0110)\end{array}$ & $\begin{array}{c}.094 \\
(.0057)\end{array}$ \\
\hline Constant & $\begin{array}{c}8.790 \\
(.0195)\end{array}$ & $\begin{array}{c}8.827 \\
(.0173)\end{array}$ & $\begin{array}{c}8.719 \\
(.0406)\end{array}$ & $\begin{array}{c}8.741 \\
(.0170)\end{array}$ & $\begin{array}{c}8.912 \\
(.0129)\end{array}$ & $\begin{array}{c}9.031 \\
(.0110)\end{array}$ & $\begin{array}{c}9.187 \\
(.0242)\end{array}$ & $\begin{array}{c}8.970 \\
(.0122)\end{array}$ \\
\hline
\end{tabular}


Table 5 - Counterfactual Gender Gaps, 1998 - Percentages

(Counterfactuals Constructed Using Male X's and Female $\beta$ 's)

\begin{tabular}{|c|c|c|c|c|c|c|c|}
\hline $\begin{array}{c}5^{\text {th }} \\
\text { percentile }\end{array}$ & \begin{tabular}{c|c}
$10^{\text {th }}$ \\
percentile
\end{tabular} & $\begin{array}{c}25^{\text {th }} \\
\text { percentile }\end{array}$ & $\begin{array}{c}50^{\text {th }} \\
\text { percentile }\end{array}$ & $\begin{array}{c}75^{\text {th }} \\
\text { percentile }\end{array}$ & $\begin{array}{c}90^{\text {th }} \\
\text { percentile }\end{array}$ & $\begin{array}{c}95^{\text {th }} \\
\text { percentile }\end{array}$ & OLS \\
\hline \multicolumn{8}{|c|}{ 1. Observed Gender Gap } \\
\hline $\begin{array}{l}-.048 \\
\end{array}$ & -.065 & -.098 & -.133 & -.198 & -.336 & -.387 & -.162 \\
\hline \multicolumn{8}{|c|}{ 2. Counterfactual Gap Using the Basic Control Variables } \\
\hline-.057 & -.078 & -.110 & -.142 & -.208 & -.346 & -.402 & -.171 \\
\hline \multicolumn{8}{|c|}{ 3. Counterfactual Gap Using the Basic Control Variables and Education Fields } \\
\hline-.058 & -.079 & -.109 & -.132 & -.178 & -.291 & -.331 & -.154 \\
\hline \multicolumn{8}{|c|}{ 4. Counterfactual Gap Using the Basic Control Variables, Education Fields, and Sector } \\
\hline-.063 & -.077 & -.098 & -.110 & -.156 & -.269 & -.317 & -.137 \\
\hline \multicolumn{8}{|c|}{ 5. Counterfactual Gap Using the Basic Control Variables, Education Fields, Sector, and Industry } \\
\hline-.055 & -.068 & -.086 & -.106 & -.154 & -.263 & -.310 & -.130 \\
\hline \multicolumn{8}{|c|}{$\begin{array}{l}\text { 6. Counterfactual Gap Using the Basic Control Variapless, Education Fields, Sector, Industry, and } \\
\text { Occupation }\end{array}$} \\
\hline-.079 & -.070 & -.074 & -.079 & -.091 & -.162 & -.195 & -.099 \\
\hline
\end{tabular}

${ }^{22}$ The last row is based on a sample of the data consisting of $10 \%$ of the males and $10 \%$ of the females. 


\section{Appendix:}

Table A1. Estimated wage equations using data from SLLS-91 and SSW-92 with identical regressors. Standard errors in parentheses.

\begin{tabular}{|l|c|c|c|c|c|c|}
\hline & \multicolumn{3}{|c|}{ SLLS-91 } & \multicolumn{3}{c|}{ SSW-92 } \\
\hline & All & Men & Women & All & Men & Women \\
\hline Gender & -0.195 & & & -.155 & & \\
Dummy & $(0.008)$ & & & $(0.002)$ & & \\
\hline Age & 0.031 & 0.038 & 0.025 & 0.026 & 0.032 & 0.020 \\
& $(0.002)$ & $(0.004)$ & $(0.003)$ & $(0.001)$ & $(0.001)$ & $(0.001)$ \\
\hline Age Sq./100 & -0.030 & -0.035 & -0.025 & -0.025 & -0.030 & -0.019 \\
& $(0.003)$ & $(0.005)$ & $(0.003)$ & $(0.001)$ & $(.001)$ & $(.001)$ \\
\hline Ed2 & 0.070 & 0.101 & 0.047 & 0.076 & 0.097 & 0.059 \\
& $(0.018)$ & $(0.028)$ & $(0.022)$ & $(0.005)$ & $(0.008)$ & $(0.005)$ \\
\hline Ed3 & 0.121 & 0.161 & 0.087 & 0.098 & 0.118 & 0.080 \\
& $(0.014)$ & $(0.022)$ & $(0.018)$ & $(0.004)$ & $(0.007)$ & $(0.004)$ \\
\hline Ed4 & 0.192 & 0.226 & 0.139 & 0.172 & 0.203 & 0.124 \\
& $(0.017)$ & $(0.025)$ & $(0.023)$ & $(0.005)$ & $(0.007)$ & $(0.006)$ \\
\hline Ed5 & 0.273 & 0.307 & 0.243 & 0.224 & 0.249 & 0.203 \\
& $(0.017)$ & $(0.027)$ & $(0.021)$ & $(0.005)$ & $(0.008)$ & $(.005)$ \\
\hline Ed6 & 0.365 & 0.377 & 0.353 & 0.379 & 0.409 & 0.351 \\
& $(0.017)$ & $(0.027)$ & $(0.022)$ & $(0.005)$ & $(0.008)$ & $(0.005)$ \\
\hline Ed7 & 0.444 & 0.444 & 0.475 & 0.583 & 0.602 & 0.531 \\
& $(0.045)$ & $(0.057)$ & $(0.085)$ & $(0.014)$ & $(0.019)$ & $(0.023)$ \\
\hline Constant & 3.561 & 3.351 & 3.564 & 8.876 & 8.707 & 8.897 \\
& $(0.047)$ & $(0.075)$ & $(0.056)$ & $(0.014)$ & $(0.023)$ & $(0.015)$ \\
\hline \# of obs & 3318 & 1655 & 1663 & 29281 & 14266 & 15015 \\
\hline Adj. R-sq. & 0.348 & 0.278 & 0.274 & 0.394 & 0.327 & 0.376 \\
\hline
\end{tabular}

Note: Educational levels are presented in the text. Ages: 18-65 years. 
Table A2 Quantile Log Wage Regressions, 1998: Standard Errors in Parentheses

\begin{tabular}{|c|c|c|c|c|c|c|c|c|}
\hline & $\stackrel{5^{\text {th }}}{\text { Percentile }}$ & $\underline{10^{\text {th }}}$ & $\begin{array}{c}25^{\text {th }} \\
\text { Percentile }\end{array}$ & $\begin{array}{c}50^{\text {th }} \\
\text { Percentile } \\
\underline{\underline{n}}\end{array}$ & $\begin{array}{c}\frac{75^{\text {th }}}{\text { Percentile }} \\
\end{array}$ & $\begin{array}{c}90^{\text {th }} \\
\text { Percentile }\end{array}$ & $\begin{array}{c}95^{\text {th }} \\
\text { Percentile }\end{array}$ & $\underline{\text { OLS }}$ \\
\hline $\begin{array}{l}\text { Gender } \\
\text { Dummy }\end{array}$ & $\begin{array}{c}-.059 \\
(.0021)\end{array}$ & $\begin{array}{c}-.079 \\
(.0014)\end{array}$ & $\begin{array}{c}-.115 \\
(.0012)\end{array}$ & $\begin{array}{c}-.158 \\
(.0013)\end{array}$ & $\begin{array}{c}-.211 \\
(.0022)\end{array}$ & $\begin{array}{c}-.266 \\
(.0032)\end{array}$ & $\begin{array}{c}-.293 \\
(.0046)\end{array}$ & $\begin{array}{c}-.174 \\
(.0015)\end{array}$ \\
\hline Age & $\begin{array}{c}.027 \\
(.0007)\end{array}$ & $\begin{array}{c}.026 \\
(.0005)\end{array}$ & $\begin{array}{c}.025 \\
(.0004)\end{array}$ & $\begin{array}{c}.026 \\
(.0004)\end{array}$ & $\begin{array}{c}.030 \\
(.0007)\end{array}$ & $\begin{array}{c}.035 \\
(.0011)\end{array}$ & $\begin{array}{c}.039 \\
(.0015)\end{array}$ & $\begin{array}{c}.031 \\
(.0005)\end{array}$ \\
\hline $\begin{array}{l}\text { Age } \\
\text { Sq. } / 100\end{array}$ & $\begin{array}{c}-.026 \\
(.0009)\end{array}$ & $\begin{array}{c}-.026 \\
(.0006)\end{array}$ & $\begin{array}{c}-.024 \\
(.0005)\end{array}$ & $\begin{array}{c}-.025 \\
(.0005)\end{array}$ & $\begin{array}{c}-.029 \\
(.0009)\end{array}$ & $\begin{array}{c}-.033 \\
(.0013)\end{array}$ & $\begin{array}{c}-.037 \\
(.0019)\end{array}$ & $\begin{array}{c}-.029 \\
(.0006)\end{array}$ \\
\hline$\overline{E d} 2$ & $\begin{array}{c}.006 \\
(.0051)\end{array}$ & $\begin{array}{c}.014 \\
(.0036)\end{array}$ & $\begin{array}{c}.036 \\
(.0029)\end{array}$ & $\begin{array}{c}.055 \\
(.0032)\end{array}$ & $\begin{array}{c}.080 \\
(.0054)\end{array}$ & $\begin{array}{l}.126 \\
(.0078)\end{array}$ & $\begin{array}{c}.165 \\
(.0113)\end{array}$ & $\begin{array}{c}.068 \\
(.0037)\end{array}$ \\
\hline Ed3 & $\begin{array}{c}.047 \\
(.0045)\end{array}$ & $\begin{array}{c}.049 \\
(.0031)\end{array}$ & $\begin{array}{c}.065 \\
(.0025)\end{array}$ & $\begin{array}{c}.077 \\
(.0028)\end{array}$ & $\begin{array}{c}.086 \\
(.0046)\end{array}$ & $\begin{array}{c}.108 \\
(.0067)\end{array}$ & $\begin{array}{c}.139 \\
(.0097)\end{array}$ & $\begin{array}{c}.087 \\
(.0032)\end{array}$ \\
\hline$\overline{E d 4}$ & $\begin{array}{c}.057 \\
(.0048)\end{array}$ & $\begin{array}{c}.069 \\
(.0034)\end{array}$ & $\begin{array}{l}.101 \\
(.0027)\end{array}$ & $\begin{array}{c}.138 \\
(.0031)\end{array}$ & $\begin{array}{c}.192 \\
(.0052)\end{array}$ & $\begin{array}{c}.262 \\
(.0076)\end{array}$ & $\begin{array}{c}.325 \\
(.0110)\end{array}$ & $\begin{array}{c}.171 \\
(.0035)\end{array}$ \\
\hline Ed5 & $\begin{array}{c}.126 \\
(.0049)\end{array}$ & $\begin{array}{c}.140 \\
(.0034)\end{array}$ & $\begin{array}{l}.171 \\
(.0027)\end{array}$ & $\begin{array}{c}.207 \\
(.0031)\end{array}$ & $\begin{array}{c}.251 \\
(.0051)\end{array}$ & $\begin{array}{c}.321 \\
(.0074)\end{array}$ & $\begin{array}{c}.384 \\
(.0108)\end{array}$ & $\begin{array}{c}.234 \\
(.0035)\end{array}$ \\
\hline Ed6 & $\begin{array}{c}.210 \\
(.0049)\end{array}$ & $\begin{array}{c}.231 \\
(.0033)\end{array}$ & $\begin{array}{c}.276 \\
(.0027)\end{array}$ & $\begin{array}{c}.339 \\
(.0031)\end{array}$ & $\begin{array}{c}.451 \\
(.0051)\end{array}$ & $\begin{array}{c}.587 \\
(.0074)\end{array}$ & $\begin{array}{c}.667 \\
(.0108)\end{array}$ & $\begin{array}{c}.391 \\
(.0035)\end{array}$ \\
\hline Ed7 & $\begin{array}{c}.352 \\
(.0115)\end{array}$ & $\begin{array}{c}.407 \\
(.0080)\end{array}$ & $\begin{array}{c}.488 \\
(.0066)\end{array}$ & $\begin{array}{c}.590 \\
(.0073)\end{array}$ & $\begin{array}{c}.702 \\
(.0122)\end{array}$ & $\begin{array}{c}.783 \\
(.0176)\end{array}$ & $\begin{array}{c}.780 \\
(.0252)\end{array}$ & $\begin{array}{c}.600 \\
(.0084)\end{array}$ \\
\hline Imm & $\begin{array}{c}-.158 \\
(.0070) \\
\end{array}$ & $\begin{array}{c}-.141 \\
(.0049) \\
\end{array}$ & $\begin{array}{c}.128 \\
(.0040) \\
\end{array}$ & $\begin{array}{c}-.103 \\
(.0044) \\
\end{array}$ & $\begin{array}{c}-.097 \\
(.0073) \\
\end{array}$ & $\begin{array}{c}.099 \\
(.0106) \\
\end{array}$ & $\begin{array}{c}-.100 \\
(.0152) \\
\end{array}$ & $\begin{array}{c}-.127 \\
(.0050) \\
\end{array}$ \\
\hline Constant & $\begin{array}{c}8.841 \\
(.0152)\end{array}$ & $\begin{array}{c}8.897 \\
(.0104)\end{array}$ & $\begin{array}{c}9.000 \\
(.0081)\end{array}$ & $\begin{array}{c}9.087 \\
(.0087)\end{array}$ & $\begin{array}{c}9.122 \\
(.0142)\end{array}$ & $\begin{array}{c}9.153 \\
(.0210)\end{array}$ & $\begin{array}{c}9.150 \\
(.0305)\end{array}$ & $\begin{array}{c}8.995 \\
(.0099)\end{array}$ \\
\hline
\end{tabular}


Table A3 Quantile Log Wage Regressions, 1991: Standard Errors in Parentheses

\begin{tabular}{|c|c|c|c|c|c|c|c|c|}
\hline & $\frac{5^{\text {th }}}{\text { Percentile }}$ & $\frac{10^{\text {th }}}{\text { Percentile }}$ & $\begin{array}{c}25^{\text {th }} \\
\text { Percentile }\end{array}$ & $\begin{array}{c}50^{\text {th }} \\
\text { Percentile }\end{array}$ & 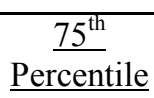 & 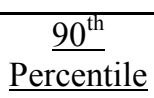 & $\begin{array}{c}95^{\text {th }} \\
\text { Percentile }\end{array}$ & $\underline{\mathrm{OLS}}$ \\
\hline $\begin{array}{l}\text { Gender } \\
\text { Dummy }\end{array}$ & $\begin{array}{l}-.128 \\
(.0177)\end{array}$ & $\begin{array}{c}-.136 \\
(.0104)\end{array}$ & $\begin{array}{c}-.138 \\
(.0078)\end{array}$ & $\begin{array}{c}-.170 \\
(.0083)\end{array}$ & $\begin{array}{c}.243 \\
(.0085)\end{array}$ & $\begin{array}{c}-.292 \\
(.0179)\end{array}$ & $\begin{array}{c}-.302 \\
(.0282)\end{array}$ & $\begin{array}{l}-.196 \\
(.008)\end{array}$ \\
\hline Age & $\begin{array}{c}.031 \\
(.0053)\end{array}$ & $\begin{array}{c}.034 \\
(.0031)\end{array}$ & $\begin{array}{c}.029 \\
(.0023)\end{array}$ & $\begin{array}{c}.027 \\
(.0023)\end{array}$ & $\begin{array}{c}.034 \\
(.0024)\end{array}$ & $\begin{array}{c}.031 \\
(.0050)\end{array}$ & $\begin{array}{c}.023 \\
(.0079)\end{array}$ & $\begin{array}{c}.032 \\
(.0023)\end{array}$ \\
\hline $\begin{array}{l}\text { Age } \\
\text { Sq./100 }\end{array}$ & $\begin{array}{c}-.029 \\
(.0063)\end{array}$ & $\begin{array}{c}-.034 \\
(.0038)\end{array}$ & $\begin{array}{l}-.029 \\
(.0027)\end{array}$ & $\begin{array}{c}.026 \\
(.0028)\end{array}$ & $\begin{array}{c}.033 \\
(.0029)\end{array}$ & $\begin{array}{c}.029 \\
(.0062)\end{array}$ & $\begin{array}{c}.017 \\
(.0098)\end{array}$ & $\begin{array}{c}.031 \\
(.0028)\end{array}$ \\
\hline$\overline{E d} 2$ & $\begin{array}{c}.009 \\
(.0379)\end{array}$ & $\begin{array}{c}.017 \\
(.0222)\end{array}$ & $\begin{array}{c}.048 \\
(.0167)\end{array}$ & $\begin{array}{c}.060 \\
(.0176)\end{array}$ & $\begin{array}{c}.078 \\
(.0182)\end{array}$ & $\begin{array}{c}.096 \\
(.0381)\end{array}$ & $\begin{array}{c}.100 \\
(.0612)\end{array}$ & $\begin{array}{c}.068 \\
(.0176)\end{array}$ \\
\hline$\overline{E d} 3$ & $\begin{array}{c}.102 \\
(.0327)\end{array}$ & $\begin{array}{c}.087 \\
(.0185)\end{array}$ & $\begin{array}{c}.088 \\
(.0137)\end{array}$ & $\begin{array}{c}.098 \\
(.0143)\end{array}$ & $\begin{array}{c}.117 \\
(.0147)\end{array}$ & $\begin{array}{c}.141 \\
(.0316)\end{array}$ & $\begin{array}{c}.107 \\
(.0510)\end{array}$ & $\begin{array}{c}.118 \\
(.0143)\end{array}$ \\
\hline Ed4 & $\begin{array}{c}.143 \\
(.0375)\end{array}$ & $\begin{array}{c}.121 \\
(.0215)\end{array}$ & $\begin{array}{c}.149 \\
(.0159)\end{array}$ & $\begin{array}{c}.155 \\
(.0170)\end{array}$ & $\begin{array}{c}.184 \\
(.0178)\end{array}$ & $\begin{array}{c}.264 \\
(.0381)\end{array}$ & $\begin{array}{c}.301 \\
(.0597)\end{array}$ & $\begin{array}{c}.190 \\
(.0170)\end{array}$ \\
\hline Ed5 & $\begin{array}{c}.188 \\
(.0369)\end{array}$ & $\begin{array}{c}.212 \\
(.0216)\end{array}$ & $\begin{array}{c}.207 \\
(.0160)\end{array}$ & $\begin{array}{c}.235 \\
(.0170)\end{array}$ & $\begin{array}{c}.278 \\
(.0177)\end{array}$ & $\begin{array}{c}.351 \\
(.0381)\end{array}$ & $\begin{array}{c}.392 \\
(.0602)\end{array}$ & $\begin{array}{c}.269 \\
(.0170)\end{array}$ \\
\hline$\overline{E d 6}$ & $\begin{array}{c}.194 \\
(.0371)\end{array}$ & $\begin{array}{c}.243 \\
(.0220)\end{array}$ & $\begin{array}{c}.299 \\
(.0164)\end{array}$ & $\begin{array}{c}.341 \\
(.0175)\end{array}$ & $\begin{array}{c}.378 \\
(.0182)\end{array}$ & $\begin{array}{c}.489 \\
(.0385)\end{array}$ & $\begin{array}{c}.524 \\
(.060)\end{array}$ & $\begin{array}{c}.362 \\
(.0175)\end{array}$ \\
\hline$\overline{E d} 7$ & $\begin{array}{c}.022 \\
(.0821)\end{array}$ & $\begin{array}{c}.203 \\
(.0568)\end{array}$ & $\begin{array}{c}.236 \\
(.0413)\end{array}$ & $\begin{array}{c}.445 \\
(.0444)\end{array}$ & $\begin{array}{c}.664 \\
(.0453)\end{array}$ & $\begin{array}{c}.787 \\
(.0979)\end{array}$ & $\begin{array}{c}.685 \\
(.1306)\end{array}$ & $\begin{array}{c}.446 \\
(.0449)\end{array}$ \\
\hline Imm & $\begin{array}{c}-.129 \\
(.0327)\end{array}$ & $\begin{array}{c}-.105 \\
(.0203)\end{array}$ & $\begin{array}{c}.083 \\
(.0151)\end{array}$ & $\begin{array}{c}.093 \\
(.0162)\end{array}$ & $\begin{array}{c}.077 \\
(.0167)\end{array}$ & $\begin{array}{c}.080 \\
(.0350)\end{array}$ & $\begin{array}{c}. .102 \\
(.0546\end{array}$ & $\begin{array}{c}.100 \\
(.0161)\end{array}$ \\
\hline Constant & $\begin{array}{c}3.269 \\
(.1079)\end{array}$ & $\begin{array}{c}3.300 \\
(.0645)\end{array}$ & $\begin{array}{c}3.490 \\
(.0463)\end{array}$ & $\begin{array}{c}3.639 \\
(.0466)\end{array}$ & $\begin{array}{c}3.676 \\
(.0468)\end{array}$ & $\begin{array}{c}3.849 \\
(.0981)\end{array}$ & $\begin{array}{c}4.079 \\
(.1498)\end{array}$ & $\begin{array}{c}3.549 \\
(.0466)\end{array}$ \\
\hline
\end{tabular}

\begin{tabular}{|l|c|c|c|c|c|c|c|c|}
\hline Gender & -.128 & -.118 & -.121 & -.158 & -.231 & -.278 & -.262 & -.182 \\
Dummy & $(.0160)$ & $(.0102)$ & $(.0079)$ & $(.0089)$ & $(.0111)$ & $(.0176)$ & $(.0250))$ & $(.0083)$ \\
\hline Exp & .018 & .018 & .017 & .017 & .020 & .023 & .022 & .021 \\
& $(.0024)$ & $(.0016)$ & $(.0012)$ & $(.0013)$ & $(.0016)$ & $(.0026)$ & $(.0037)$ & $(.0012)$ \\
\hline Exp & -.029 & -.030 & -.028 & -.028 & -.034 & -.038 & -.028 & -.033 \\
Sq/100 & $(.0051)$ & $(.0033)$ & $(.0026)$ & $(.0029)$ & $(.0037)$ & $(.0059)$ & $(.0081)$ & $(.0027)$ \\
\hline Tenure & .004 & .004 & .003 & .002 & .001 & .000 & -.002 & .001 \\
& $(.0011)$ & $(.0007)$ & $(.0005)$ & $(.0006)$ & $(.0007)$ & $(.0012)$ & $(.0017)$ & $(.0005)$ \\
\hline Ed2 & .042 & .023 & .031 & .035 & .072 & .052 & .104 & .051 \\
& $(.0333)$ & $(.0213)$ & $(.0165)$ & $(.0188)$ & $(.0236)$ & $(.0389)$ & $(.0573)$ & $(.0176)$ \\
\hline Ed3 & .137 & .091 & .079 & .083 & .103 & .111 & .122 & .111 \\
& $(.0287)$ & $(.0181)$ & $(.0137)$ & $(.0154)$ & $(.0192)$ & $(.0322)$ & $(.0483)$ & $(.0144)$ \\
\hline Ed4 & .165 & .142 & .143 & .146 & .188 & .250 & .321 & .193 \\
& $(.0333)$ & $(.0209)$ & $(.0160)$ & $(.0182)$ & $(.0229)$ & $(.0381)$ & $(.0571)$ & $(.0170)$ \\
\hline Ed5 & .260 & .226 & .208 & .234 & .290 & .340 & .419 & .284 \\
& $(.0341)$ & $(.0214)$ & $(.0163)$ & $(.0185)$ & $(.0232)$ & $(.0389)$ & $(.0579)$ & $(.0172)$ \\
\hline Ed6 & .270 & .300 & .329 & .365 & .403 & .473 & .597 & .394 \\
& $(.0345)$ & $(.0219)$ & $(.0168)$ & $(.0192)$ & $(.0240)$ & $(.0393)$ & $(.0583)$ & $(.0179)$ \\
\hline Ed7 & .151 & .273 & .229 & .475 & .713 &. .785 & .749 & .486 \\
& $(.0728)$ & $(.0546)$ & $(.0410)$ & $(.0471)$ & $(.0587)$ & $(.0833)$ & $(.0531)$ & $(.0446)$ \\
\hline Imm & -.075 & -.076 & -.059 & -.045 & -.044 & -.042 & -.076 & -.070 \\
& $(.0280)$ & $(.0192)$ & $(.0149)$ & $(.0171)$ & $(.0214)$ & $(.0344)$ & $(.0515)$ & $(.0160)$ \\
\hline Constant & 3.713 & 3.826 & 3.948 & 4.072 & 4.200 & 4.335 & 4.399 & 4.048 \\
& $(.0362)$ & $(.0235)$ & $(.0174)$ & $(.0192)$ & $(.0238)$ & $(.0378)$ & $(.0559)$ & $(.0180)$ \\
\hline
\end{tabular}


Table A4: Quantile Log Wage Regressions comparing 1991 and 1992: Standard Errors in Parentheses

\begin{tabular}{|c|c|c|c|c|c|c|c|c|}
\hline \multicolumn{9}{|c|}{1991} \\
\hline & $\frac{5^{\text {th }}}{\text { Percentile }}$ & $\frac{10^{\text {th }}}{\text { Percentile }}$ & $\begin{array}{c}25^{\text {th }} \\
\text { Percentile }\end{array}$ & $\frac{50^{\text {th }}}{\text { Percentile }}$ & $\frac{75^{\text {th }}}{\text { Percentile }}$ & $\begin{array}{c}\frac{90^{\text {th }}}{\text { Percentile }} \\
\text { ercen }\end{array}$ & $\begin{array}{c}\frac{95^{\text {th }}}{\text { Percentile }} \\
\underline{\text { ercen }}\end{array}$ & OLS \\
\hline $\begin{array}{l}\text { Gender } \\
\text { Dummy }\end{array}$ & $\begin{array}{c}-.134 \\
(.0177) \\
\end{array}$ & $\begin{array}{c}. .131 \\
(.0107) \\
\end{array}$ & $\begin{array}{c}-.137 \\
(.0088) \\
\end{array}$ & $\begin{array}{c}-.168 \\
(.0079) \\
\end{array}$ & $\begin{array}{c}-.241 \\
(.0091) \\
\end{array}$ & $\begin{array}{c}-.297 \\
(.0182) \\
\end{array}$ & $\begin{array}{c}.306 \\
(.0274) \\
\end{array}$ & $\begin{array}{c}-195 \\
(.0083) \\
\end{array}$ \\
\hline Age & $\begin{array}{c}.030 \\
(.0052)\end{array}$ & $\begin{array}{c}.033 \\
(.0031)\end{array}$ & $\begin{array}{c}.027 \\
(.0025)\end{array}$ & $\begin{array}{c}.028 \\
(.0022)\end{array}$ & $\begin{array}{c}.033 \\
(.0025)\end{array}$ & $\begin{array}{c}.031 \\
(.0051)\end{array}$ & $\begin{array}{c}.022 \\
(.0076)\end{array}$ & $\begin{array}{c}.031 \\
(.0023)\end{array}$ \\
\hline $\begin{array}{l}\text { Age } \\
\text { Sq/100 }\end{array}$ & $\begin{array}{c}-.029 \\
(.0062)\end{array}$ & $\begin{array}{c}-.033 \\
(.0038)\end{array}$ & $\begin{array}{l}-.026 \\
(.0031)\end{array}$ & $\begin{array}{l}-.027 \\
(.0027)\end{array}$ & $\begin{array}{l}-.033 \\
(.0031)\end{array}$ & $\begin{array}{c}-.029 \\
(.0063)\end{array}$ & $\begin{array}{l}-.016 \\
(.0094)\end{array}$ & $\begin{array}{c}.030 \\
(.0029)\end{array}$ \\
\hline $\mathrm{Ed} 2$ & $\begin{array}{c}.012 \\
(.0377)\end{array}$ & $\begin{array}{c}.028 \\
(.0227)\end{array}$ & $\begin{array}{c}.052 \\
(.0187)\end{array}$ & $\begin{array}{c}.061 \\
(.0169)\end{array}$ & $\begin{array}{c}.085 \\
(.0193)\end{array}$ & $\begin{array}{c}.106 \\
(.0384)\end{array}$ & $\begin{array}{c}.099 \\
(.0586)\end{array}$ & $\begin{array}{c}.070 \\
(.0177)\end{array}$ \\
\hline $\mathrm{Ed} 3$ & $\begin{array}{c}.107 \\
(.0326) \\
\end{array}$ & $\begin{array}{c}.099 \\
(.0191) \\
\end{array}$ & $\begin{array}{c}.091 \\
(.0153) \\
\end{array}$ & $\begin{array}{c}.098 \\
(.0138) \\
\end{array}$ & $\begin{array}{c}.121 \\
(.0156) \\
\end{array}$ & $\begin{array}{c}.149 \\
(.0319) \\
\end{array}$ & $\begin{array}{l}.101 \\
(.0489) \\
\end{array}$ & $\begin{array}{c}.121 \\
(.0144) \\
\end{array}$ \\
\hline Ed4 & $\begin{array}{c}.127 \\
(.0371)\end{array}$ & $\begin{array}{l}.128 \\
(.0220)\end{array}$ & $\begin{array}{c}.146 \\
(.0179)\end{array}$ & $\begin{array}{c}.157 \\
(.0163)\end{array}$ & $\begin{array}{c}.193 \\
(.0188)\end{array}$ & $\begin{array}{c}.277 \\
(.0385)\end{array}$ & $\begin{array}{c}.299 \\
(.0573)\end{array}$ & $\begin{array}{c}.192 \\
(.0171)\end{array}$ \\
\hline$\overline{E d 5}$ & $\begin{array}{c}.187 \\
(.0366) \\
\end{array}$ & $\begin{array}{c}.221 \\
(.0220) \\
\end{array}$ & $\begin{array}{c}.207 \\
(.0180) \\
\end{array}$ & $\begin{array}{c}.236 \\
(.0163) \\
\end{array}$ & $\begin{array}{c}.284 \\
(.0189) \\
\end{array}$ & $\begin{array}{c}.366 \\
(.0386) \\
\end{array}$ & $\begin{array}{c}.393 \\
(.0575) \\
\end{array}$ & $\begin{array}{c}.273 \\
(.0171) \\
\end{array}$ \\
\hline$\overline{E d 6}$ & $\begin{array}{c}.189 \\
(.0375)\end{array}$ & $\begin{array}{c}.253 \\
(.0225)\end{array}$ & $\begin{array}{c}.289 \\
(.0184)\end{array}$ & $\begin{array}{c}.345 \\
(.0168)\end{array}$ & $\begin{array}{c}.387 \\
(.0193)\end{array}$ & $\begin{array}{c}.491 \\
(.0389)\end{array}$ & $\begin{array}{c}.522 \\
(.0582)\end{array}$ & $\begin{array}{c}.365 \\
(.0176)\end{array}$ \\
\hline Ed7 & $\begin{array}{l}-.101 \\
(.0816)\end{array}$ & $\begin{array}{c}.220 \\
(.0582)\end{array}$ & $\begin{array}{c}.246 \\
(.0463)\end{array}$ & $\begin{array}{c}.450 \\
(.0425)\end{array}$ & $\begin{array}{c}.672 \\
(.0483)\end{array}$ & $\begin{array}{c}.801 \\
(.0846)\end{array}$ & $\begin{array}{c}.687 \\
(.1267)\end{array}$ & $\begin{array}{c}.444 \\
(.0452)\end{array}$ \\
\hline Constant & $\begin{array}{c}3.284 \\
(.1072)\end{array}$ & $\begin{array}{c}3.304 \\
(.0649)\end{array}$ & $\begin{array}{c}3.535 \\
(.0518)\end{array}$ & $\begin{array}{c}3.619 \\
(.0446)\end{array}$ & $\begin{array}{c}3.665 \\
(.0503)\end{array}$ & $\begin{array}{c}3.840 \\
(.1006)\end{array}$ & $\begin{array}{c}4.090 \\
(.1465)\end{array}$ & $\begin{array}{c}3.561 \\
(.0468)\end{array}$ \\
\hline
\end{tabular}

\begin{tabular}{|c|c|c|c|c|c|c|c|c|}
\hline \multicolumn{9}{|c|}{$\underline{1992}$} \\
\hline & $\stackrel{5^{\text {th }}}{\text { Percentile }}$ & $\underline{10^{\text {th }}}$ & 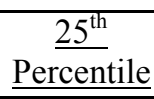 & $\begin{array}{c}50^{\text {th }} \\
\text { Percentile } \\
\underline{\underline{n}}\end{array}$ & $\underline{\underline{75^{\text {th }}}}$ & $\begin{array}{c}90^{\text {th }} \\
\text { Percentile } \\
\end{array}$ & $\begin{array}{c}95^{\text {th }} \\
\text { Percentile } \\
\end{array}$ & $\underline{\text { OLS }}$ \\
\hline $\begin{array}{l}\text { Gender } \\
\text { Dummy }\end{array}$ & $\begin{array}{l}.061 \\
(.0035)\end{array}$ & $\begin{array}{c}-.070 \\
(.0025)\end{array}$ & $\begin{array}{c}.097 \\
(.0019)\end{array}$ & $\begin{array}{l}-.134 \\
(.0022)\end{array}$ & $\begin{array}{c}.188 \\
(.0033)\end{array}$ & $\begin{array}{c}-.256 \\
(.0051)\end{array}$ & $\begin{array}{c}.300 \\
(.0075)\end{array}$ & $\begin{array}{c}.155 \\
(.0023)\end{array}$ \\
\hline Age & $\begin{array}{c}.027 \\
(.0012)\end{array}$ & $\begin{array}{c}.025 \\
(.0008)\end{array}$ & $\begin{array}{c}.023 \\
(.0006)\end{array}$ & $\begin{array}{c}.021 \\
(.0007)\end{array}$ & $\begin{array}{c}.024 \\
(.0010)\end{array}$ & $\begin{array}{c}.028 \\
(.0015)\end{array}$ & $\begin{array}{c}.028 \\
(.0022)\end{array}$ & $\begin{array}{c}.026 \\
(.0007)\end{array}$ \\
\hline $\begin{array}{l}\text { Age } \\
\text { Sq/100 }\end{array}$ & $\begin{array}{c}-.027 \\
(.0014)\end{array}$ & $\begin{array}{c}-.025 \\
(.0010)\end{array}$ & $\begin{array}{c}-.022 \\
(.0007)\end{array}$ & $\begin{array}{c}-.020 \\
(.0008)\end{array}$ & $\begin{array}{c}-.023 \\
(.0012)\end{array}$ & $\begin{array}{c}.026 \\
(.0019)\end{array}$ & $\begin{array}{c}-.026 \\
(.0027)\end{array}$ & $\begin{array}{c}-.025 \\
(.0008)\end{array}$ \\
\hline Ed2 & $\begin{array}{c}.026 \\
(.0074)\end{array}$ & $\begin{array}{c}.036 \\
(.0054)\end{array}$ & $\begin{array}{c}.046 \\
(.0041)\end{array}$ & $\begin{array}{c}.065 \\
(.0047)\end{array}$ & $\begin{array}{c}.086 \\
(.0070)\end{array}$ & $\begin{array}{c}.116 \\
(.0108)\end{array}$ & $\begin{array}{c}.129 \\
(.0159)\end{array}$ & $\begin{array}{c}.076 \\
(.0049)\end{array}$ \\
\hline Ed3 & $\begin{array}{c}.060 \\
(.0062)\end{array}$ & $\begin{array}{c}.069 \\
(.0045) \\
\end{array}$ & $\begin{array}{c}.074 \\
(.0034)\end{array}$ & $\begin{array}{c}.089 \\
(.0038)\end{array}$ & $\begin{array}{c}.104 \\
(.0056)\end{array}$ & $\begin{array}{c}.120 \\
(.0086)\end{array}$ & $\begin{array}{c}.125 \\
(.0127)\end{array}$ & $\begin{array}{c}.098 \\
(.0040)\end{array}$ \\
\hline Ed4 & $\begin{array}{c}.071 \\
(.0071) \\
\end{array}$ & $\begin{array}{c}.081 \\
(.0051) \\
\end{array}$ & $\begin{array}{c}.100 \\
(.0039)\end{array}$ & $\begin{array}{c}.143 \\
(.0046)\end{array}$ & $\begin{array}{c}.204 \\
(.0069)\end{array}$ & $\begin{array}{c}.273 \\
(.0107)\end{array}$ & $\begin{array}{c}.311 \\
(.0158)\end{array}$ & $\begin{array}{c}.172 \\
(.0048)\end{array}$ \\
\hline Ed5 & $\begin{array}{c}.134 \\
(.0069)\end{array}$ & $\begin{array}{c}.154 \\
(.0050)\end{array}$ & $\begin{array}{c}.182 \\
(.0038)\end{array}$ & $\begin{array}{c}.213 \\
(.0044)\end{array}$ & $\begin{array}{c}.243 \\
(.0066)\end{array}$ & $\begin{array}{c}.282 \\
(.0103)\end{array}$ & $\begin{array}{c}.311 \\
(.0153)\end{array}$ & $\begin{array}{c}.224 \\
(.0046)\end{array}$ \\
\hline Ed6 & $\begin{array}{c}.236 \\
(.0071)\end{array}$ & $\begin{array}{c}.268 \\
(.0051)\end{array}$ & $\begin{array}{c}.297 \\
(.0039)\end{array}$ & $\begin{array}{c}.349 \\
(.0045)\end{array}$ & $\begin{array}{c}.414 \\
(.0067)\end{array}$ & $\begin{array}{c}.534 \\
(.0105)\end{array}$ & $\begin{array}{c}.607 \\
(.0155)\end{array}$ & $\begin{array}{c}.379 \\
(.0047)\end{array}$ \\
\hline Ed7 & $\begin{array}{c}.333 \\
(.0210)\end{array}$ & $\begin{array}{c}.407 \\
(.0151)\end{array}$ & $\begin{array}{c}.488 \\
(.0117)\end{array}$ & $\begin{array}{c}.559 \\
(.0134)\end{array}$ & $\begin{array}{c}.688 \\
(.0199)\end{array}$ & $\begin{array}{c}.808 \\
(.0306)\end{array}$ & $\begin{array}{c}.825 \\
(.0448)\end{array}$ & $\begin{array}{c}.583 \\
(.0140)\end{array}$ \\
\hline Constant & $\begin{array}{c}8.644 \\
(.0243)\end{array}$ & $\begin{array}{c}8.725 \\
(.0167)\end{array}$ & $\begin{array}{c}8.846 \\
(.0121)\end{array}$ & $\begin{array}{c}8.964 \\
(.0133)\end{array}$ & $\begin{array}{c}9.028 \\
(.0193)\end{array}$ & $\begin{array}{c}9.090 \\
(.0306)\end{array}$ & $\begin{array}{c}9.180 \\
(.0442)\end{array}$ & $\begin{array}{c}8.876 \\
(.0139)\end{array}$ \\
\hline
\end{tabular}




\section{References:}

Blau, Francine and Lawrence Kahn (1996), "Wage Structure and Gender Earnings Differentials: An International Comparison," Economica 63, S29-S62.

Blau, Francine and Lawrence Kahn (2000), "Gender Differences in Pay,” Journal of Economic Perspectives 14, 75-99.

Bonjour, Dorothe and Michael Gerfin (2001), "The Unequal Distribution of Unequal Pay - An Analysis of the Distribution of the Gender Wage Gap," Empirical Economics, 26, 407-427.

Brown, Charles and Corcoran Mary (1997), "Sex-Based Differences in School Content and the Male/Female Wage Gap." Journal of Labor Economics 15, 431-465.

Buchinsky, Moshe (1994), "Changes in the U.S. Wage Structure 1963-1987:Application of Quantile Regression," Econometrica 62, 405-458.

Buchinsky, Moshe (1998), "Recent Advances in Quantile Regression Models: A Practical Guideline for Empirical Research," Journal of Human Resources 33, 88-126.

Dinardo, John, Nicole Fortin, and Thomas Lemieux (1996), "Labor Market Institutions and the Distribution of Wages, 1973-1992: A Semi-Parametric Approach," Econometrica 64, 1001-1044.

Dolado, J.J., F. Felgueroso, and J.F. Jimeno (2001), "Female Employment and Occupational Changes in the 1990s: How is the EU Performing Relative to the US?," European Economic Review, Papers and Proceedings, 45, 875-889.

Donald, Stephen G., David A. Green, and Harry J. Paarsch (2000), "Differences in Wage Distributions Between Canada and the United States: An Application of a Flexible Estimator of Distribution Functions in the Presence of Covariates," Review of Economic Studies 67, 585-633.

Edin, Per-Anders and Peter Fredriksson (2000), "LINDA - Longitudinal INdividual DAta for Sweden," Working paper 2000:19, Department of Economics, Uppsala University.

Edin, Per-Anders and Katarina Richardsson (2001), "Swimming With the Tide: Solidarity Wage Policy and the Gender Earnings Gap," Scandinavian Journal of Economics, forthcoming.

Erikson, Robert and Rune Åberg (eds.) (1987), Welfare in Transition, Oxford: Clarendon Press.

Fortin, Nicole and Thomas Lemieux (1998), "Rank Regressions, Wage Distributions, and the Gender Gap," Journal of Human Resources 33, 610-43. 
Hibbs, Douglas and Håkan Locking (1996), "Wage Compression, Wage Drift, and Wage Inflation in Sweden," Labour Economics 3, 109-42

Hultin, Mia and Ryszard Szulkin (1999), "Wages and Unequal Access to Organizational Power: An Empirical Test of Gender Discrimination," Administrative Science Quarterly 44, 453-472.

Koenker, Roger and Gilbert Bassett, Jr. (1978), "Regression Quantiles," Econometrica 46, 33-50.

LeGrand, Carl (1991) "Explaining the Male-Female Wage Gap: Job Segregation and Solidarity Wage Bargaining in Sweden”, Acta Sociologica 34, 261-278.

Machado, José and José Mata (2000), “Counterfactual Decomposition of Changes in Wage Distributions using Quantile Regression," mimeo.

Meyersson-Milgrom, Eva M., Trond Petersen, and Vemund Snartland (2001), "Equal Pay for Equal Work? Evidence from Sweden, Norway and the U.S," Scandinavian Journal of Economics, forthcoming

Oaxaca, Ronald, (1973), "Male-Female Differentials in Urban Labor Markets," International Economic Review 14, 693-709.

Palme, Mårten and Robert Wright (1992), “Gender Discrimination and Compensating Differentials in Sweden," Applied Economics 24, 751-759.

Statistics Sweden (1992), Lönestatistisk Arsbok 1992.

Wright, Erik Olin, Janeen Baxter and Gunn Elisabeth Birkelund (1995), “The Gender Gap in Workplace Authority in Seven Nations," American Sociological Review 60, 407435. 


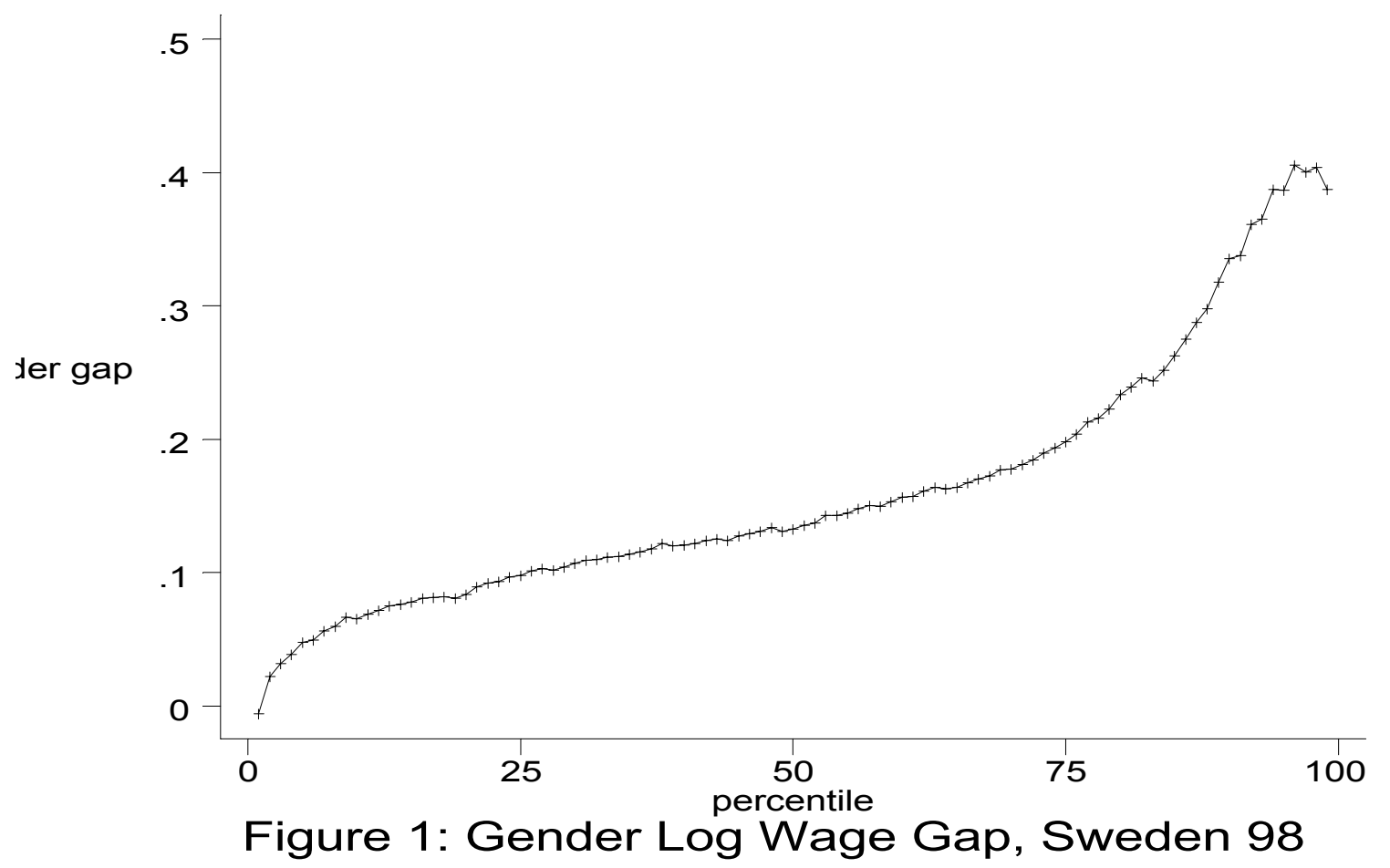




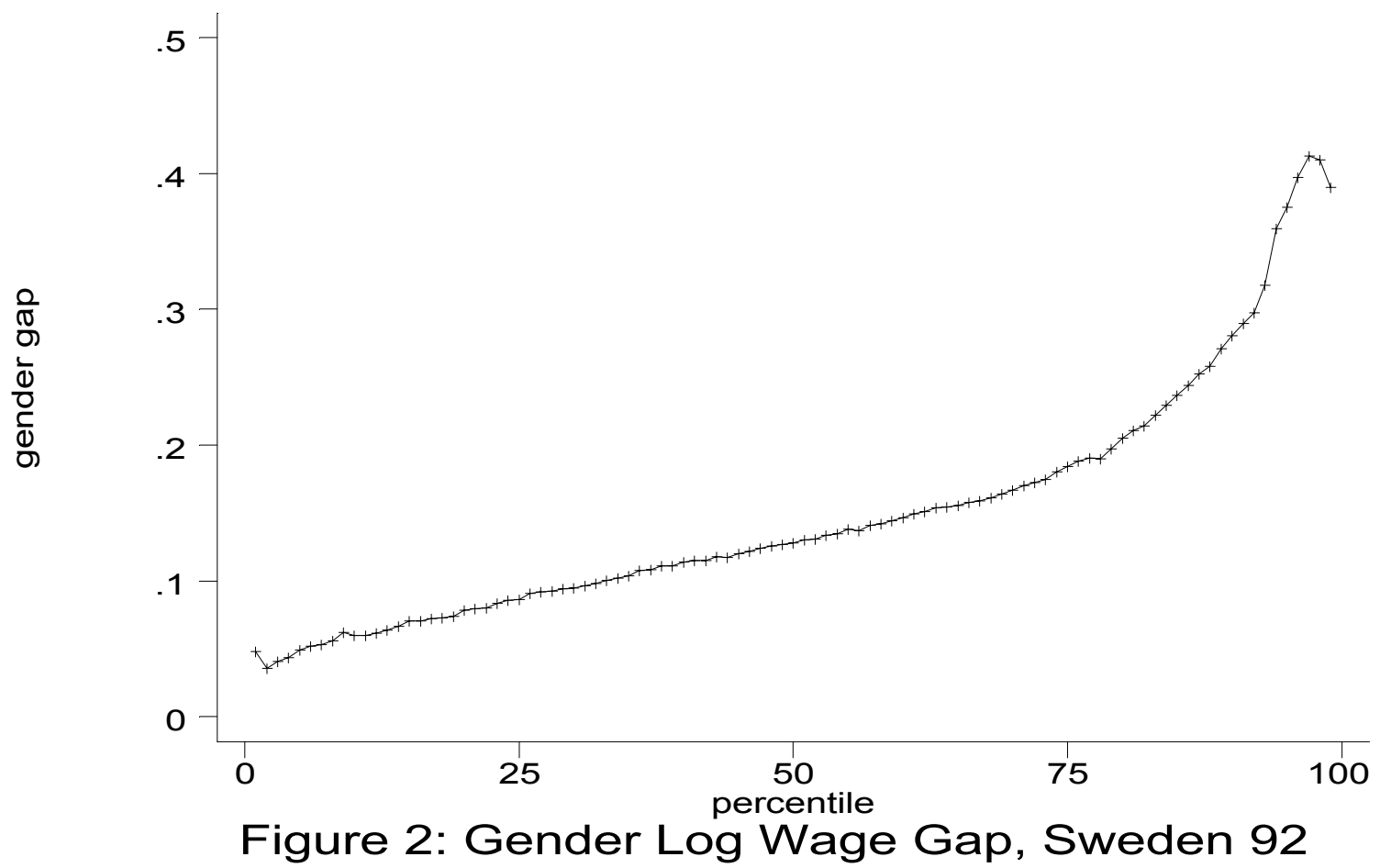




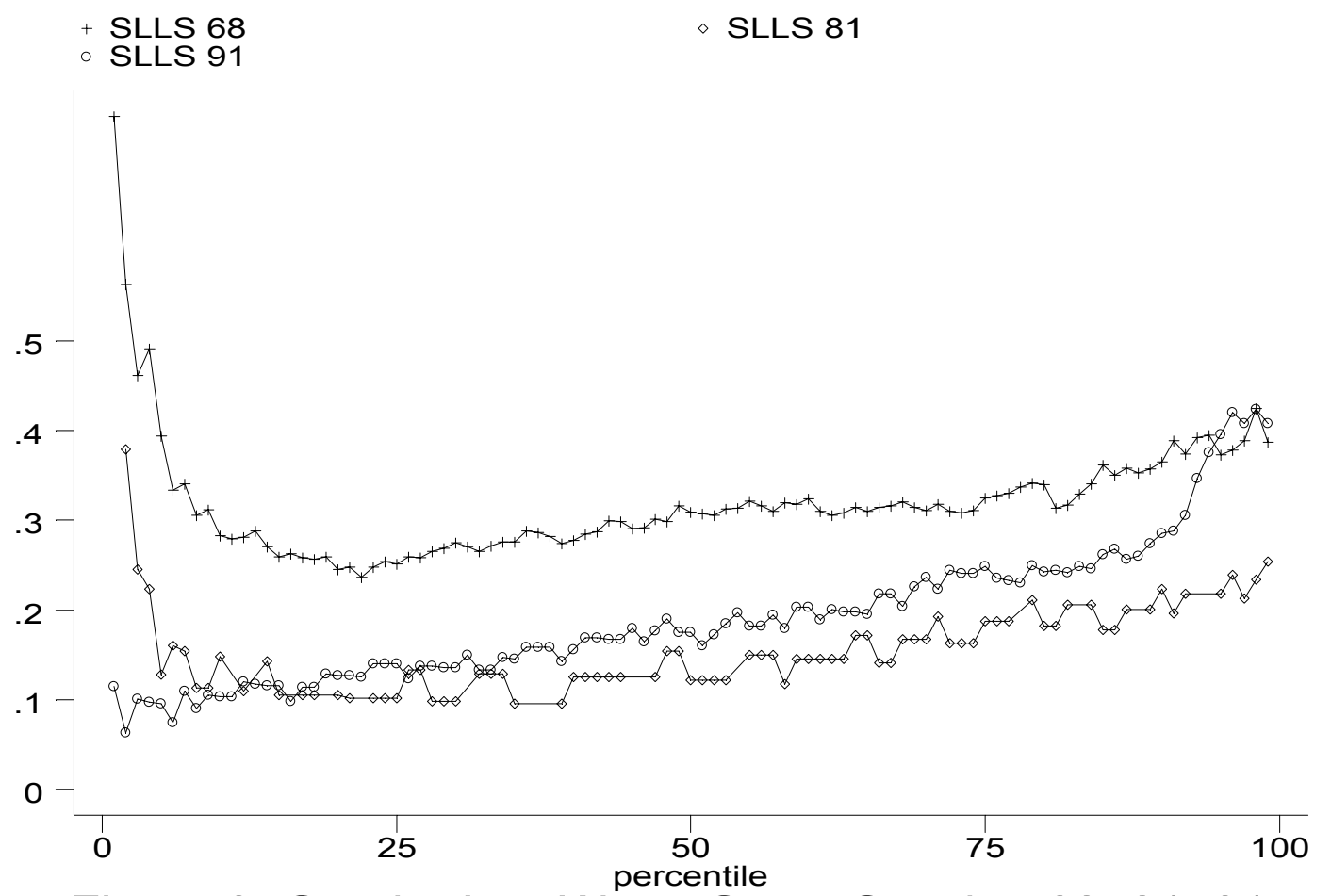

Figure 3: Gender Log Wage Gaps, Sweden 68, 81, 91 


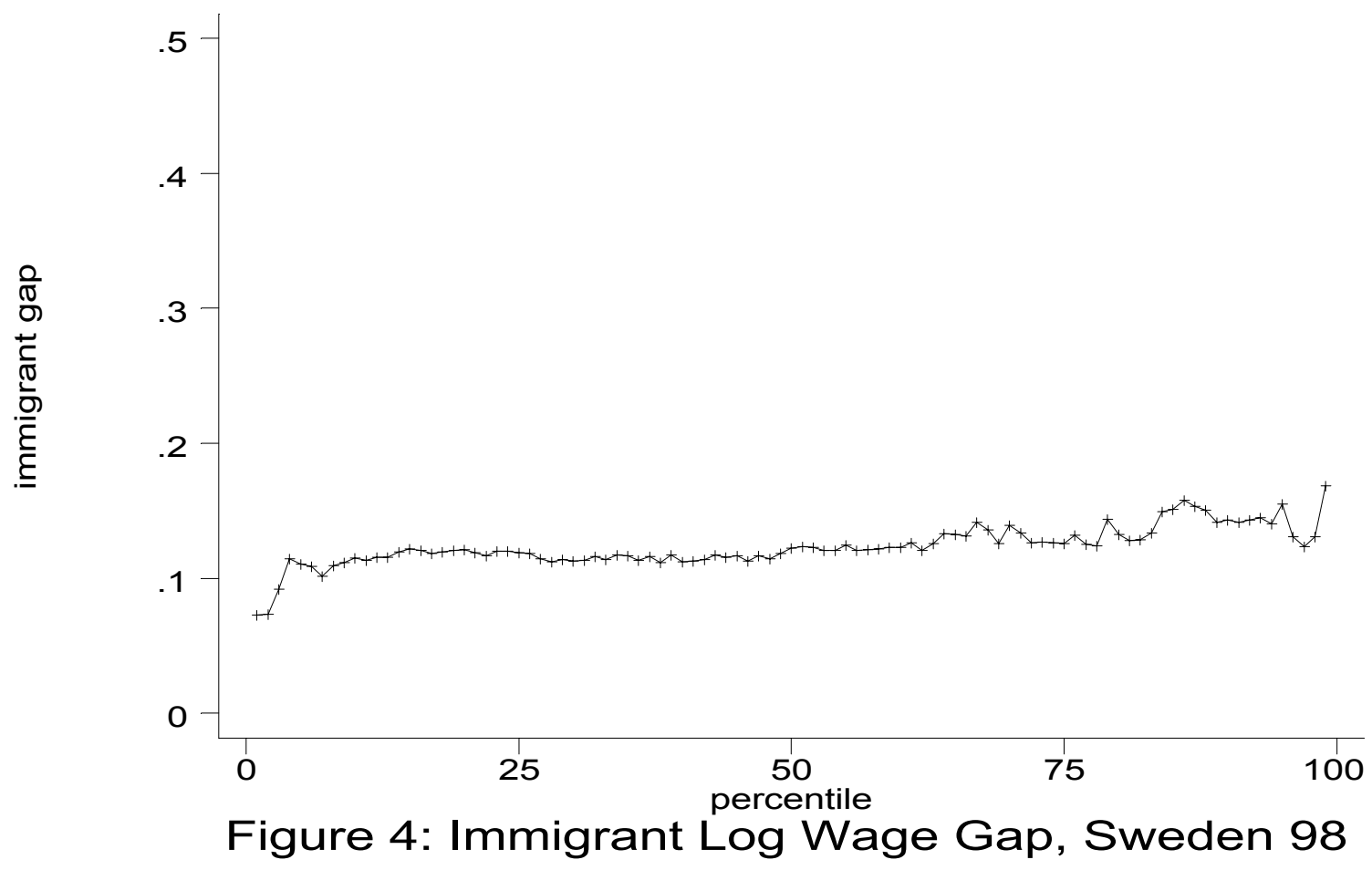




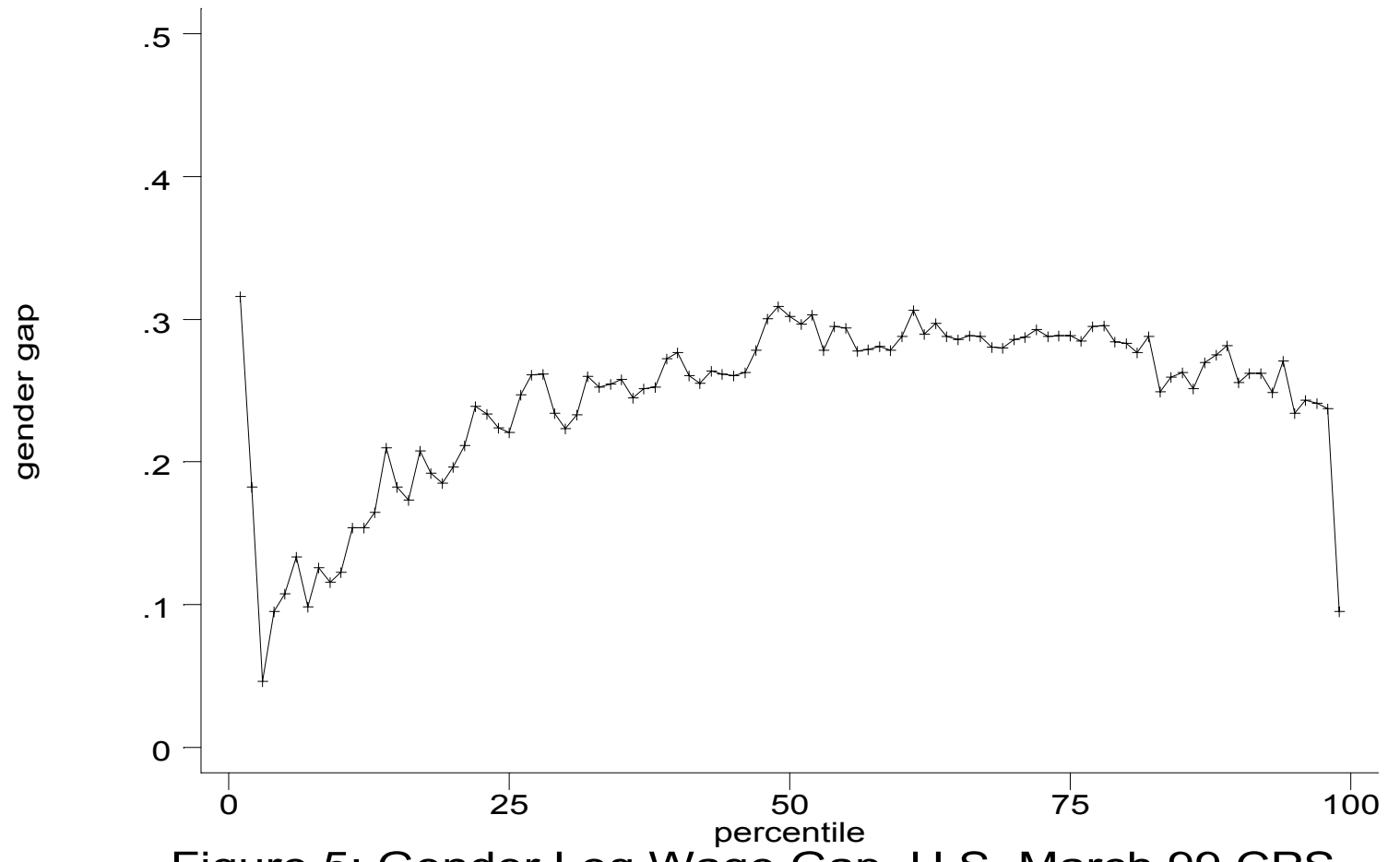

Figure 5: Gender Log Wage Gap, U.S. March 99 CPS 


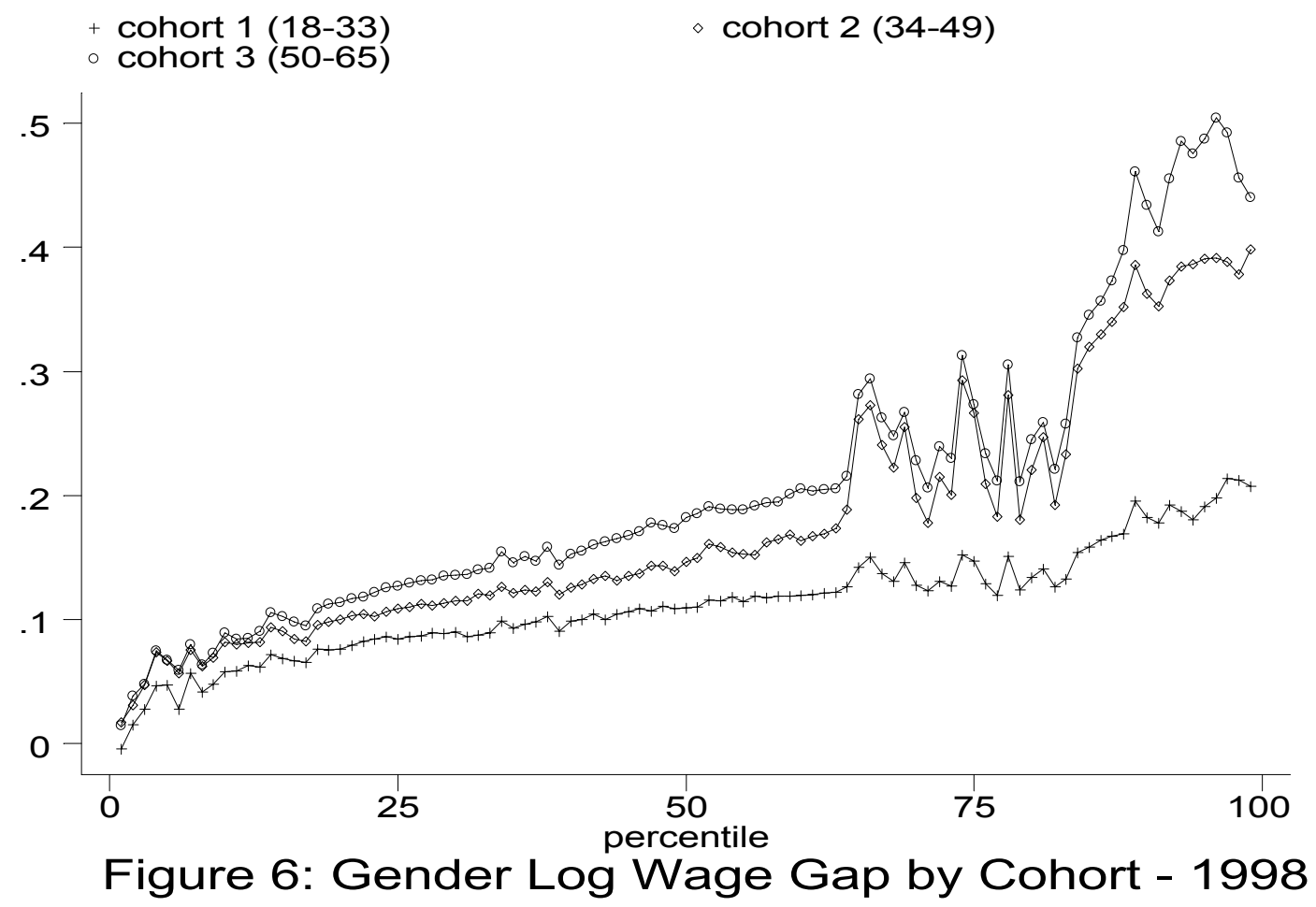




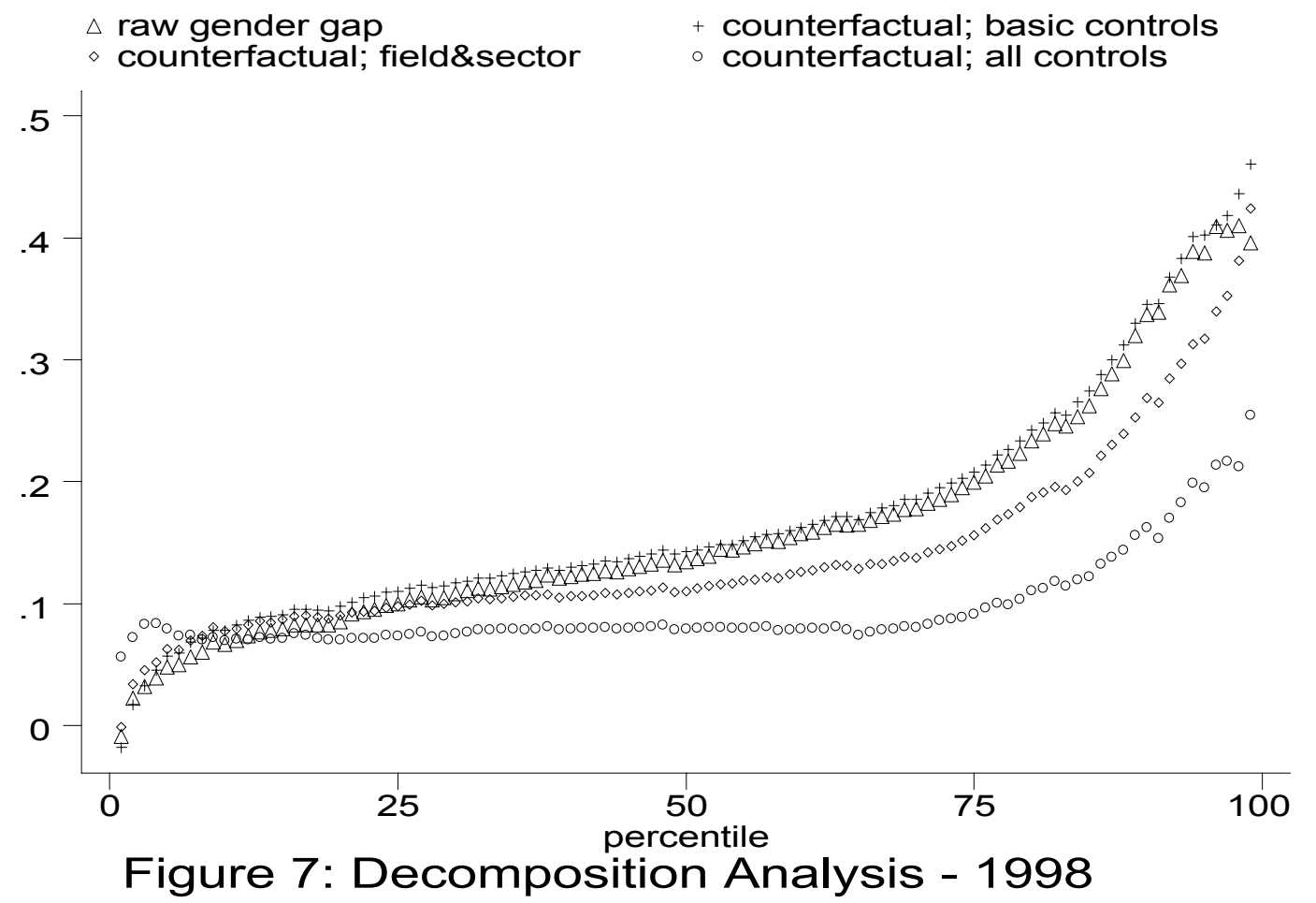

